\title{
Our Lady of Phileremos
}

\section{Historical and Archaeological Investigation}

The shrine of the Virgin on the mountain of Phileremos lies around ten kilometers southwest of the town of Rhodes, on the top of a hill overlooking the northwestern shore and the present-day village of Ialyssos/Trianda. At an altitude of 267 meters, the area served as an ideal observatory for the maritime traffic of ships (Fig. 79). From the town of Rhodes, the main road accessing Phileremos passed inland, although a coastal road was in use as well: in 1488 Jehan de Tournai followed a path along the coast that turned toward the mountain at some point. ${ }^{1}$

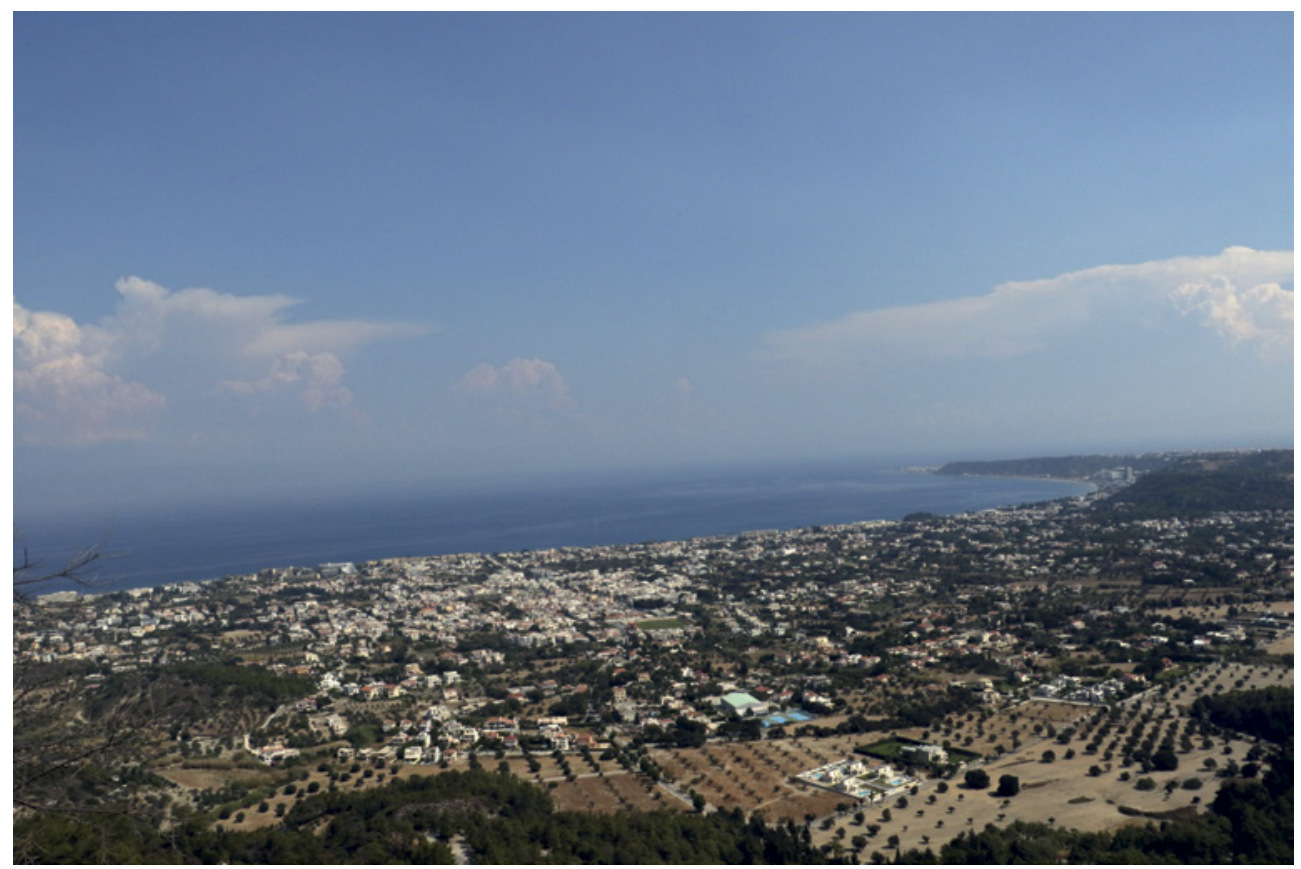

FIGURE 79 View toward the sea from Mt. Phileremos

1 Blanchet-Broekaert and Péricard-Méa 2012, 271. The inland road is attested in 1409; see Luttrell 2020, 125; Ferraris di Celle 1988, 79-80. 
The Hospitaller sanctuary is located at the site of the acropolis of the ancient city of Ialyssos, the oldest city on the island, which had been inhabited continually at least since the Geometric era. Excavations and restorations of some of the monuments were conducted by the Italian Archaeological School between the years 1914-1936..$^{2}$ The sanctuary stands on a layer of constructions all invested with religious purposes: a 1oth-century single-aisled Byzantine church, a three-aisled Early Christian basilica, and the Hellenistic temple of Athena Polias and Zeus Polieus, an earlier classical temple and a sanctuary from the Geometric age.

After the establishment of Rhodes town in the $5^{\text {th }}$ century вСE, the city of Ialyssos declined and was reduced to a town. During the Byzantine era, its history evolved along with that of the island; in theory it belonged to the Byzantine Empire, but in reality its control fell into the hands of various rulers: Greeks, Venetians, Genoese, Ottomans. ${ }^{3}$ In the 13 th century the site of the Phileremos still had a castle, a church, and a monastery. ${ }^{4}$

On November 11th, 1306, the Hospitallers occupied the castle after prevailing over 300 Ottomans who were garrisoned there, with the help of a Greek traitor. ${ }^{5}$ Subsequently, the area stayed uninhabited; in 1342 Manuel Angelos describes that only remnants of the ancient site remained. Nevertheless, there must have been a cultic focus on the site before ca. 1367 , when, possibly, the small underground church known in modern times as St. George Chostos, which lies at the northwest of the Latin Phileremos church, was decorated with frescoes, as the existence of a cultic milieu would partly justify the choice of a donor to commission these works there. ${ }^{6}$ This conclusion is corroborated by the first pilgrim account about the site by Ogier d'Anglure (1396), who attests the presence of a

2 Livadiotti and Rocco 1996, 40-46, 261-270.

3 Papachristodoulou 1972, 241-265.

4 Livadiotti and Rocco 1996, 269-270; Gallas 1985, 230-231.

5 Luttrell 1997a, 748; Luttrell 2003b, 193-195.

6 Even though the heraldic evidence is clear, the dating has been debated. Apart from the stylistic considerations that are hindered by the poor state of preservation of the murals, the identification of the coat of arms of the group of kneeling knights depicted on the south wall has been a matter of disagreement. The arms belong to the Nantouillet family; the patron of the murals was Regnault Nantouillet, who stayed for a while on Rhodes while traveling to Cyprus in order to participate in the military campaigns of Peter of Cyprus against Alexandria in 1367; see Gallas 1985, 232; Kasdagli 1988, 20; de Vaivre 2004, 919-943; Bacci 2017 b, 112-115. This dating is supported iconographically as well, especially concerning the paintings of the side walls. On the other hand, the arms have been identified with those of

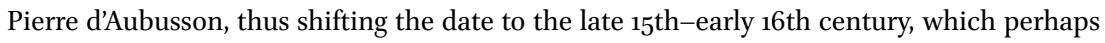
better fits stylistic elements that ascribe some of the depicted scenes in the church to this period; see Sommi Picenardi 190o, 212; Kollias 2005, fig. 68; Christoforaki 2000, 455. 
small church with two hermits, probably alluding to Greeks, and an icon that is revered by all the inhabitants of the island, "Hospitallers, Greeks, and other merchants," evidence revealing that the cult of the Virgin, as well as of the icon, was already well-rooted at Phileremos. ${ }^{7}$ Moreover, Ogier d'Anglure adds that the place was not inhabited, as also attested in 1418 by Nompar de Caumont, who describes the area in ruins, with only a chapel of the Virgin and the castle on site. ${ }^{8}$

There was a castellany in 1314, a castellan mentioned in 1329, and a castle in $1347 .{ }^{9}$ Information concerning the church edifice is lacking, but it is certain that it remained active during the 14th century. The Order gradually established its presence at the sanctuary. In 1404 the Hospitaller priest Johannes Tensac served a chaplaincy, ${ }^{10}$ and another chaplaincy in the church of St. Mary of Phileremos was founded by the Master Philibert de Naillac (1396-1421) in 1421. ${ }^{11}$ In 1476 , apart from the church, there was only a hosteria for the visiting pilgrims, which is described in 1488 as very beautiful and with very good Malvasia wine. ${ }^{12}$ In 1494 it was run by the German Hospitaller Hans Wägner. ${ }^{13}$ Almost a century after Ogier d'Anglure's visit, in 1495, there appear to have been four priests serving the church, ${ }^{14}$ and in 1497 the Master Aubusson set up a choir of four chaplains, who would offer their services exclusively in honor of the icon. ${ }^{15}$

The archaeological evidence points to three construction phases during the Hospitaller period, which may reflect the progression of the Order's actions toward the appropriation of the sanctuary (Figs. 8oa, 8ob). The first phase has been dated to the first or second half of the 14th century: it consists of a single-aisled chapel with four ribbed cross-vaults and a five-sided sanctuary apse with a rib vault. ${ }^{16}$ This was situated on top of the pre-existing north aisle of the Early Christian church. In the second phase, around 1450-1480, two sixsided chapels were added outside of two of the apse's sides, also roofed with rib vaults. ${ }^{17}$ One of these may have been the chapel that Fr. Antonio Morosini,

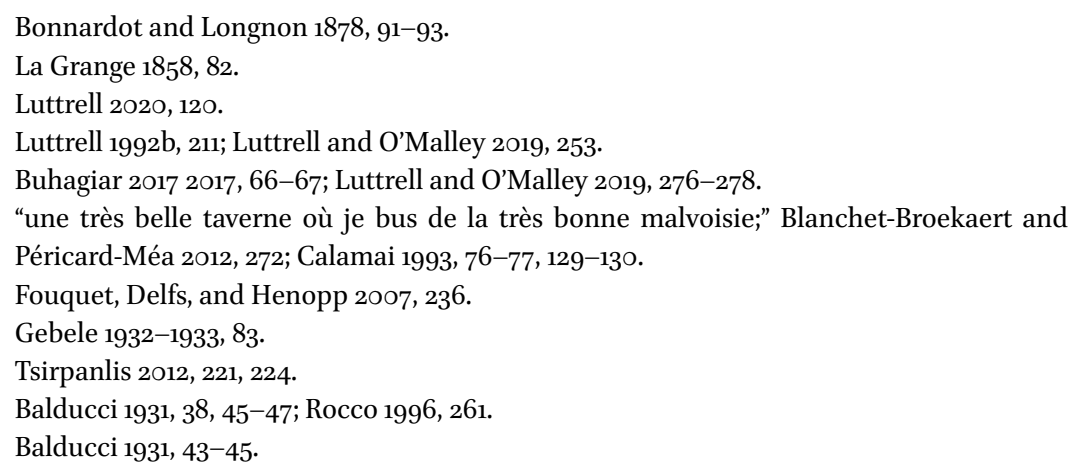




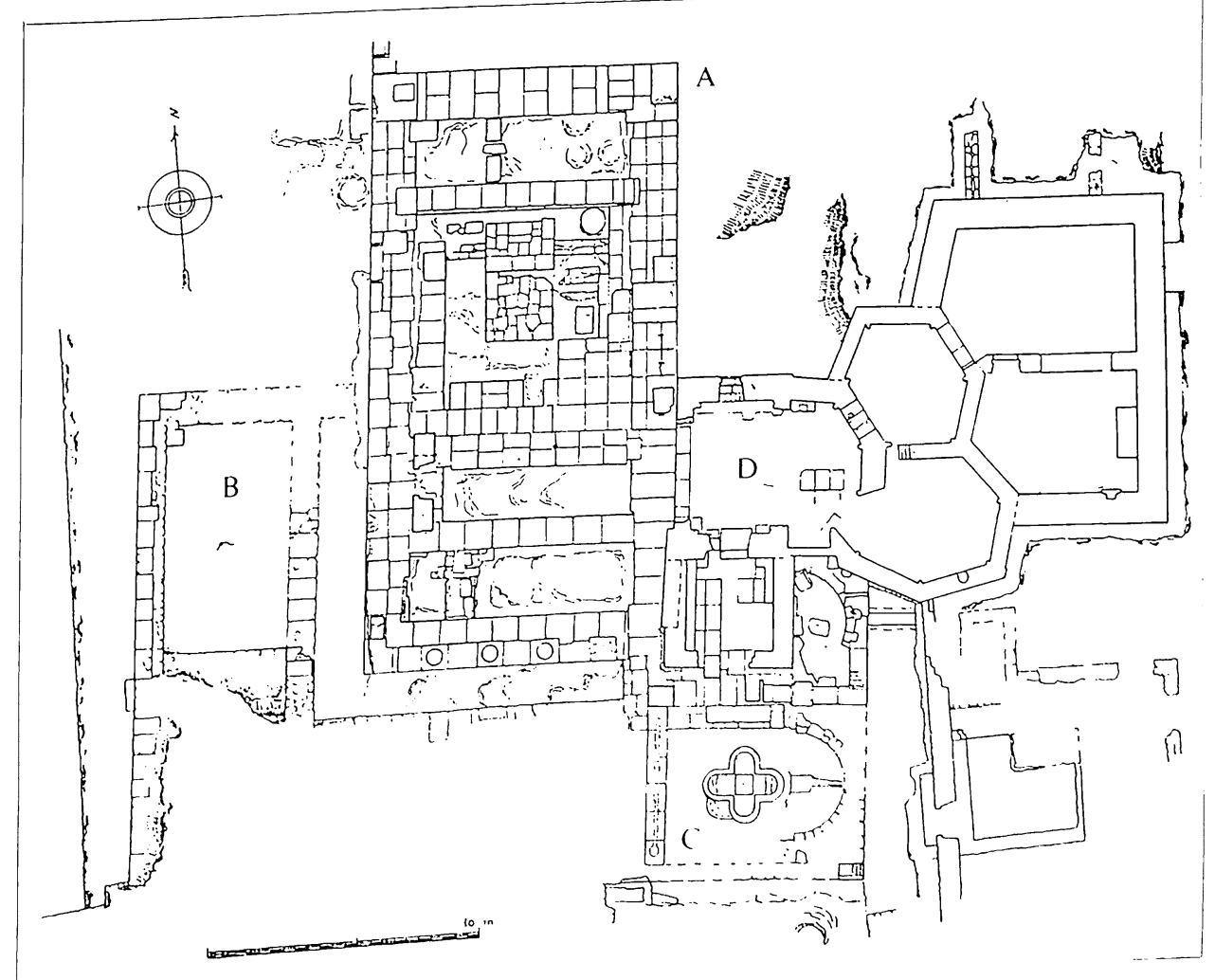

FIGURE 80A Plan depicting the construction phases at the site of the Phileremos' sanctuary, as drawn by Balducci, 1931

commander of Treviso and lieutenant of the Admiral, was licensed to build in $1439 .{ }^{18}$ All of the above were fallen when the restoration by the Italian architect Rodolfo Petracco took place in $1931^{-1935 \cdot{ }^{19}}$

After the Ottoman siege of 1480 and an earthquake in 1481 , the Master Pierre d'Aubusson restored and enlarged the church edifice, in $1489 .{ }^{20}$ This third phase mainly consisted of the addition of two parallel chapels with ribbed cross-vaults, on the east side of the previously built hexagonal ones (Figs. 81a, 81b). The depictions by Rottiers attest that in the mid-19th century there was a much larger part of the sanctuary standing, including parts of the

18 Luttrell 2020, 122.

19 Rocco 1996, 261-264.

$20 \quad$ Sommi Picenardi 1900, 211, 216. 


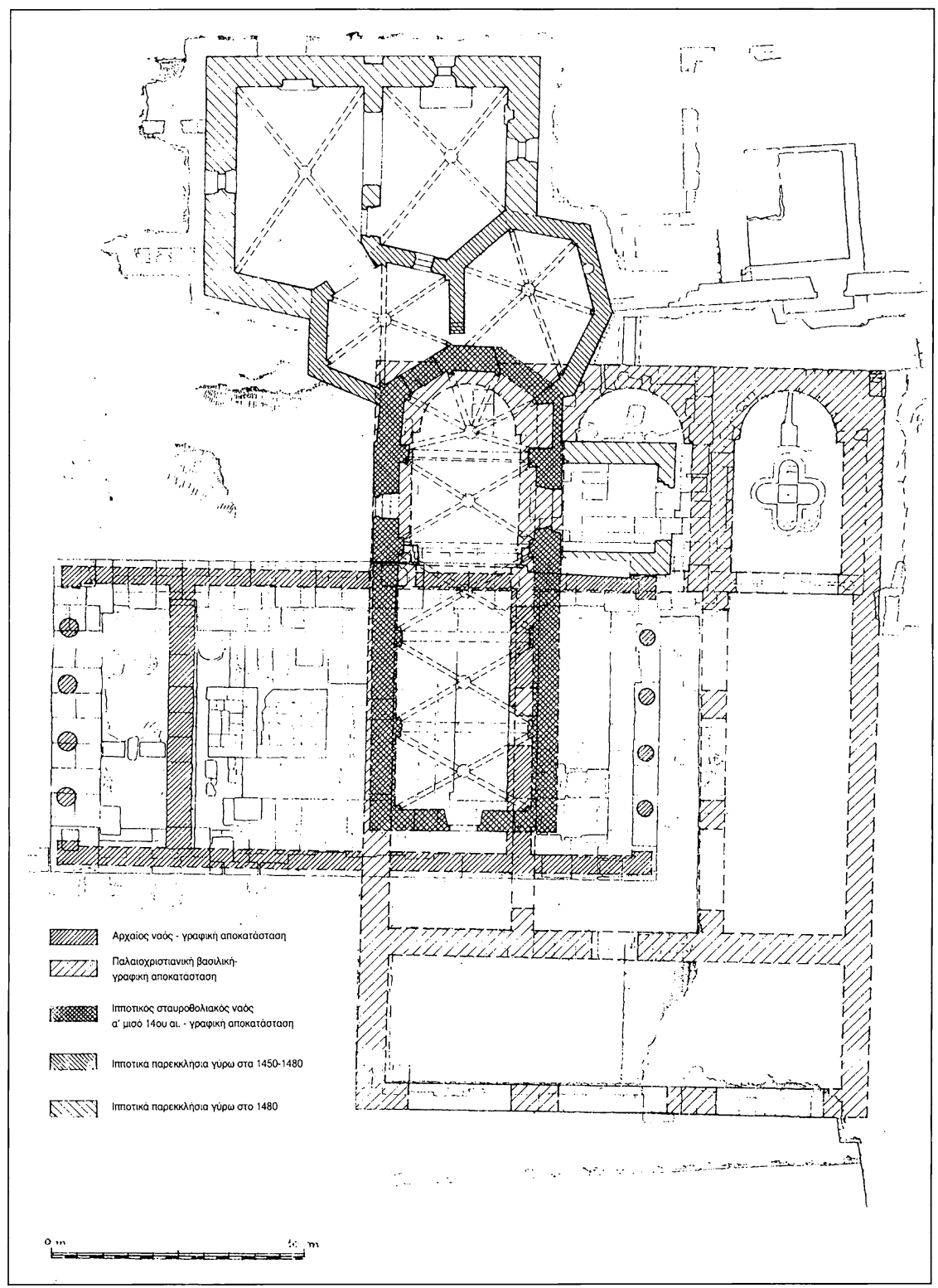

FIGURE $80 \mathrm{~B}$ Plan depicting the construction phases at the site of the Phileremos' sanctuary, as drawn by Ntellas, 2000 


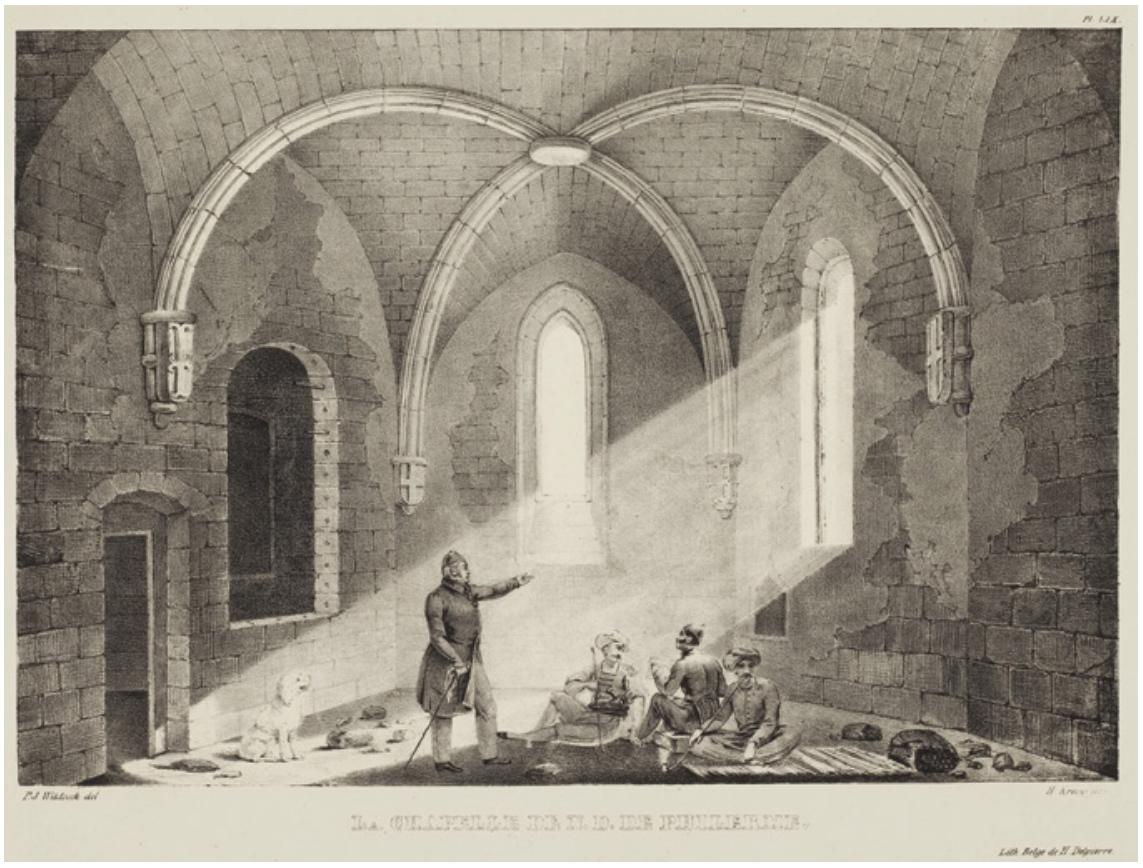

FIGURE 81A The church of Our Lady of Phileremos, with Aubusson's coats of arms visible on the corbels, 1828, lithograph after P. J. Witdoeck

two first phases as well. ${ }^{21}$ Aubusson's chapels, still standing in the early 20 th century, were consolidated in 1919 by the Italian army under the supervision of Amedeo Maiuri, an effort that respected the medieval monument (Figs. 82a, 82 b). ${ }^{22}$ Later on, in 1931-1936, as part of extended interventions at the site, the eastern cross vault of the main church, the five-sided apse, and the four chapels were reconstructed, and a bell tower was added at its southeastern side (Figs. 83a, 83b, 83c, 83d). However, these monumental reconstructions were based on inexistent clues, as nothing had remained of the masonry. The result does not seem to have taken into account the material past of the edifice: the works rather followed the style of Fascist architecture of the period. ${ }^{23}$ During this restoration, a Franciscan monastery was also erected to the east of the church.

The chapel of St. George Chostos, situated approximately 100 meters to the northwest of the church, is subterranean with a rectangular plan. It does not

21 Rottiers 1828 , pls. $58,60,67$.

22 Rocco 1996, 261-264.

23 Ntellas 2ooob, 358-36o; Rocco 1996, 263-264. 


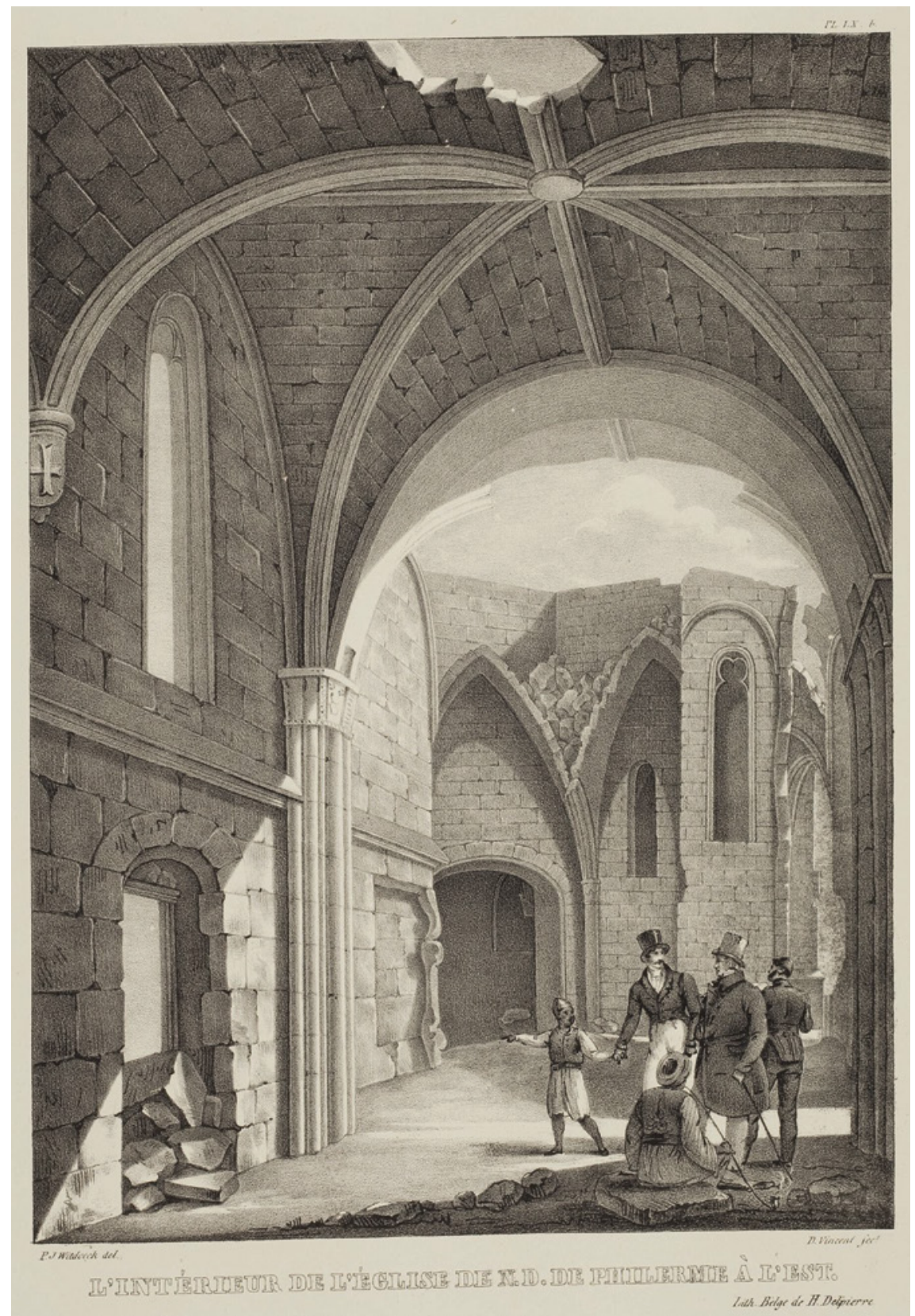

FIGURE 81B The interior of the church of Phileremos to the east, 1828, lithograph after P. J. Witdoeck 


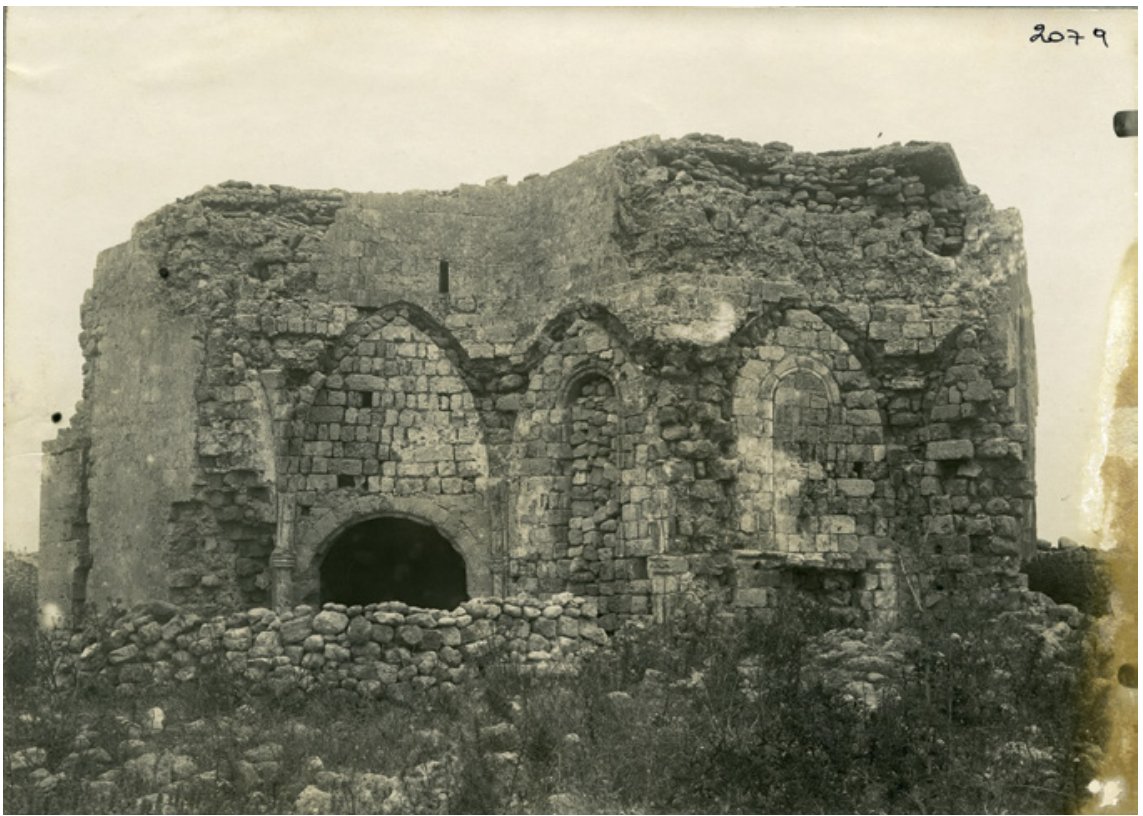

FIGURE 82A The restauration of Aubusson's chapels in 1919. South side before restauration

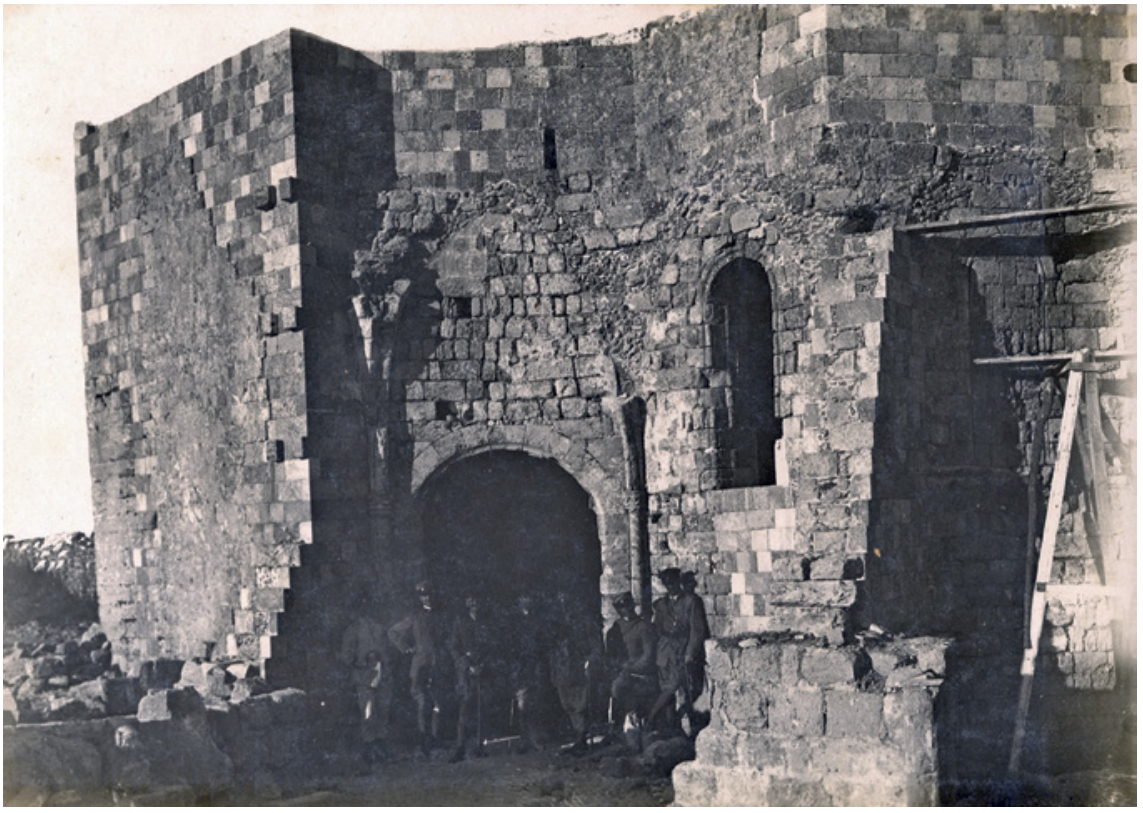

FIGURE $82 \mathrm{~B}$

The restauration of Aubusson's chapels in 1919. South side during restauration 


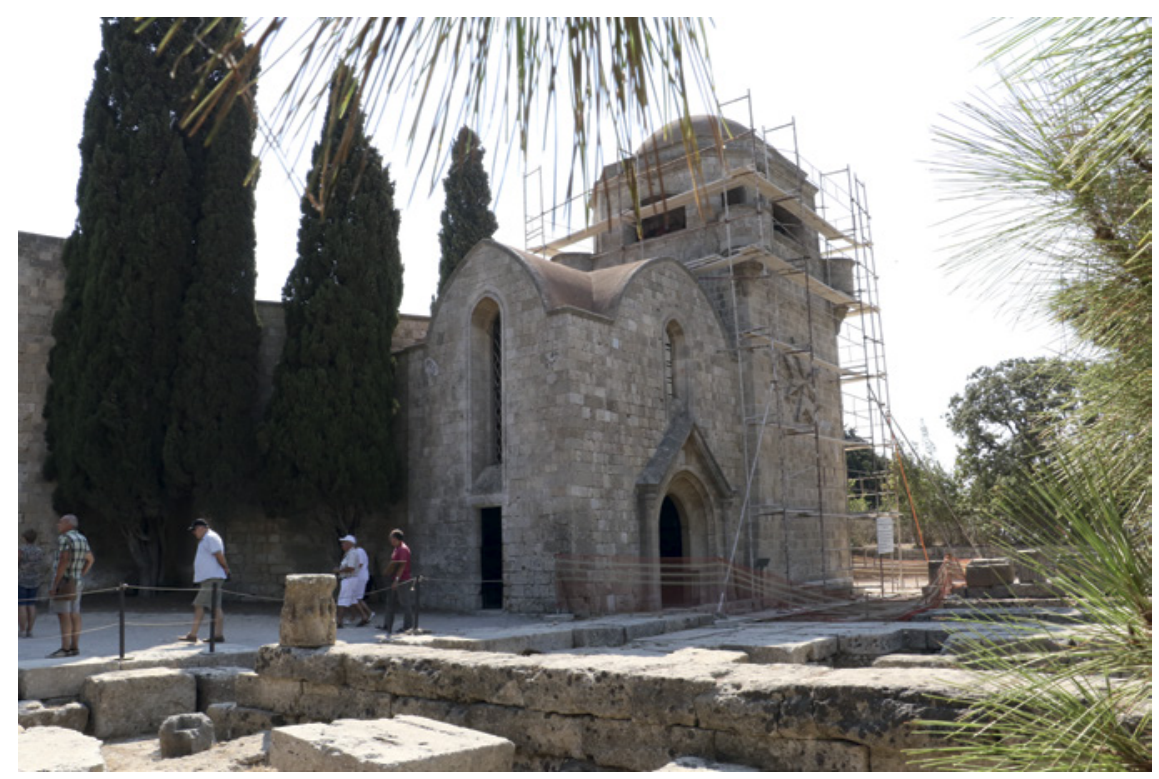

FIGURE 83A The church of the Phileremos, view from the northwest

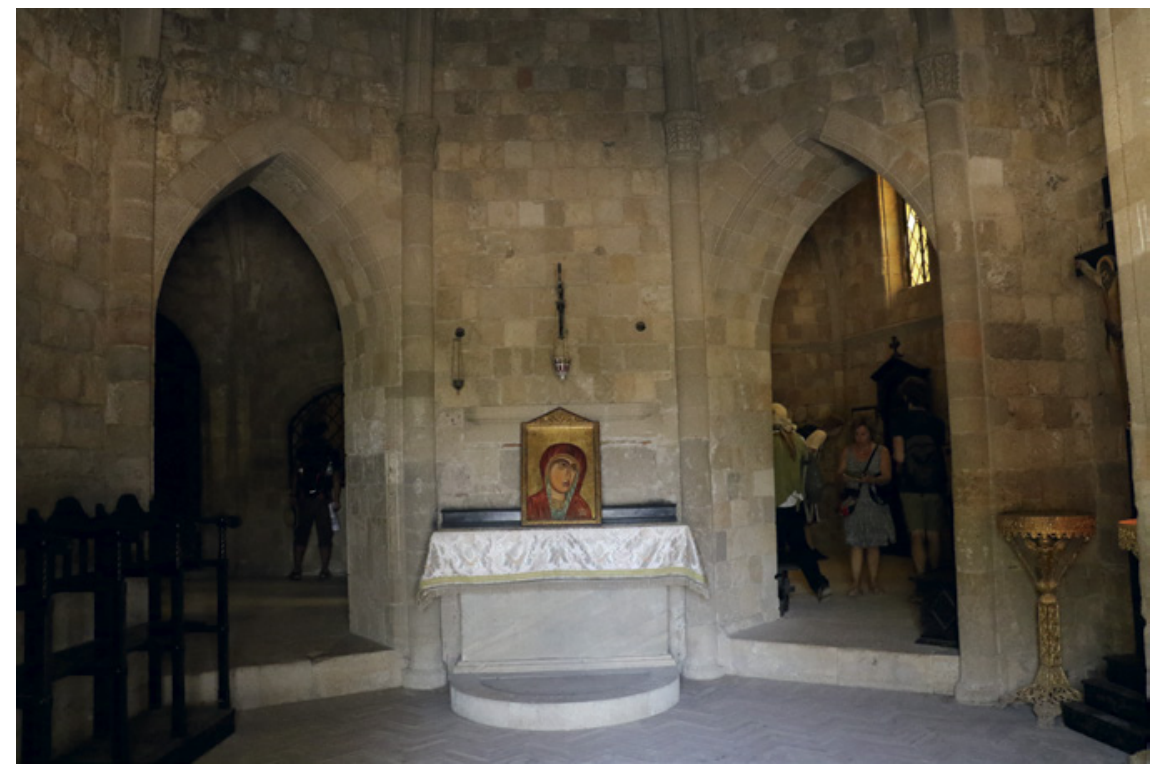

FIGURE 83B The church of the Phileremos, west entrance 


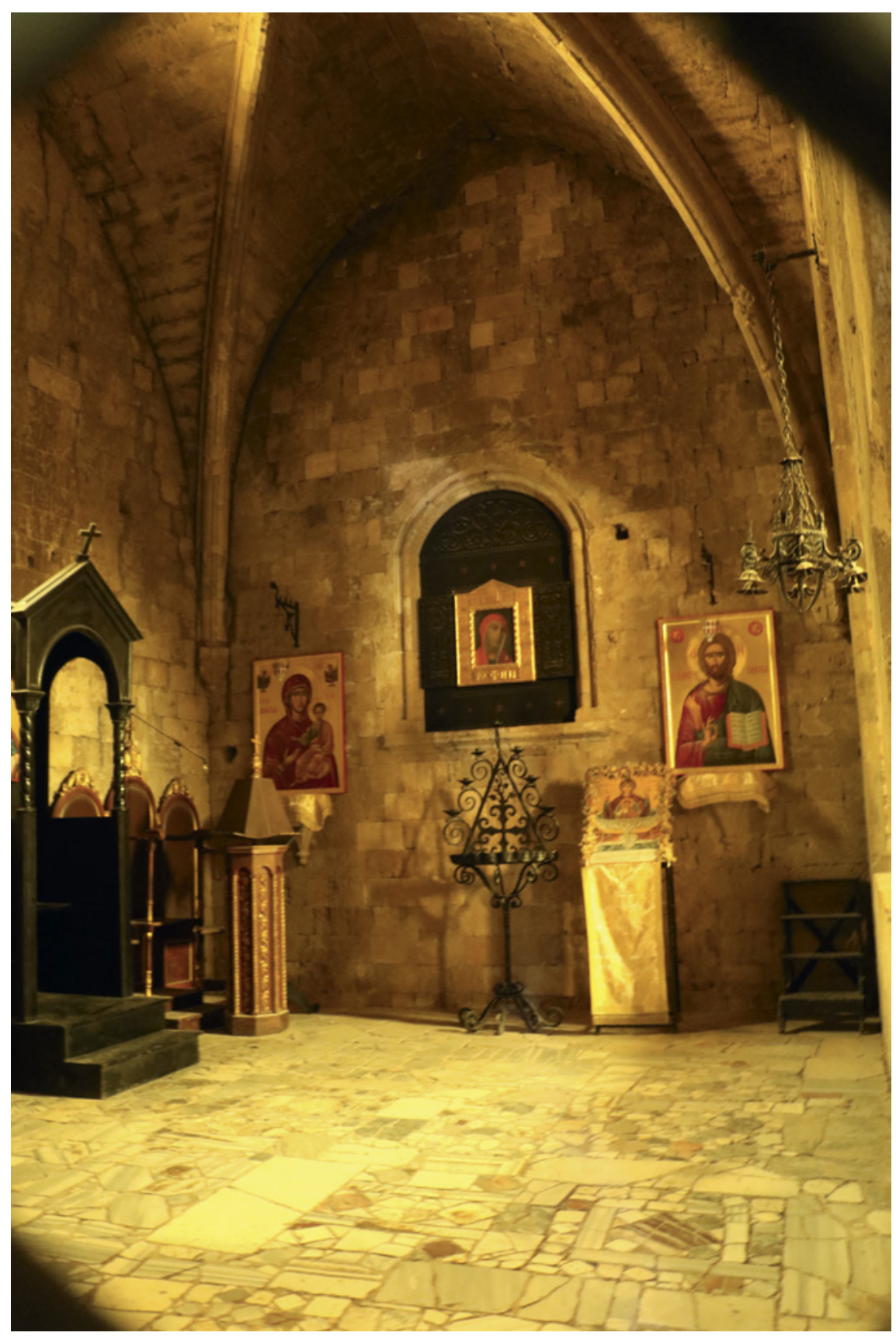

FIGURE 83C The church of the Phileremos, Aubusson's north chapel 


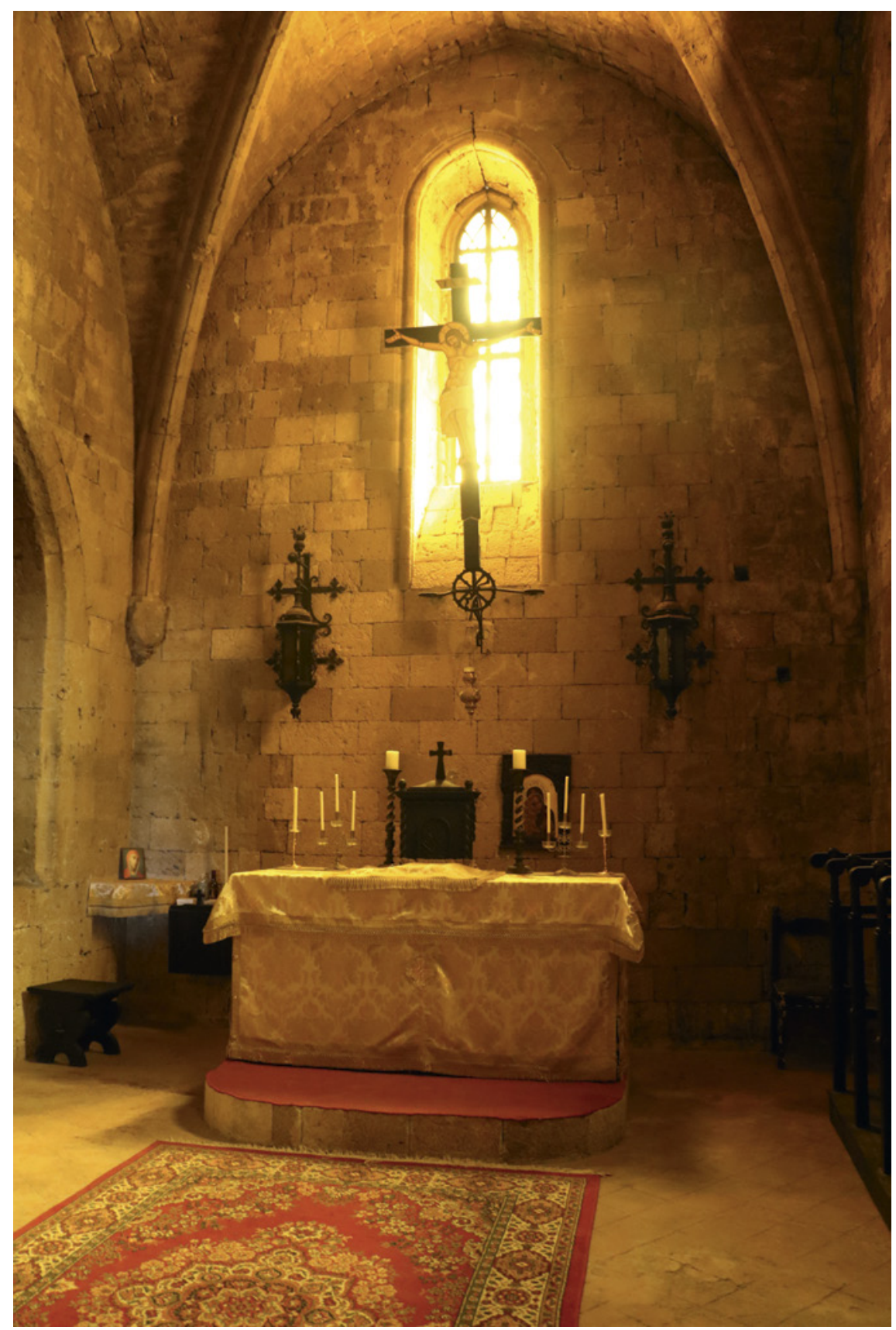

FIGURE 83D The church of the Phileremos, Aubusson's south chapel 


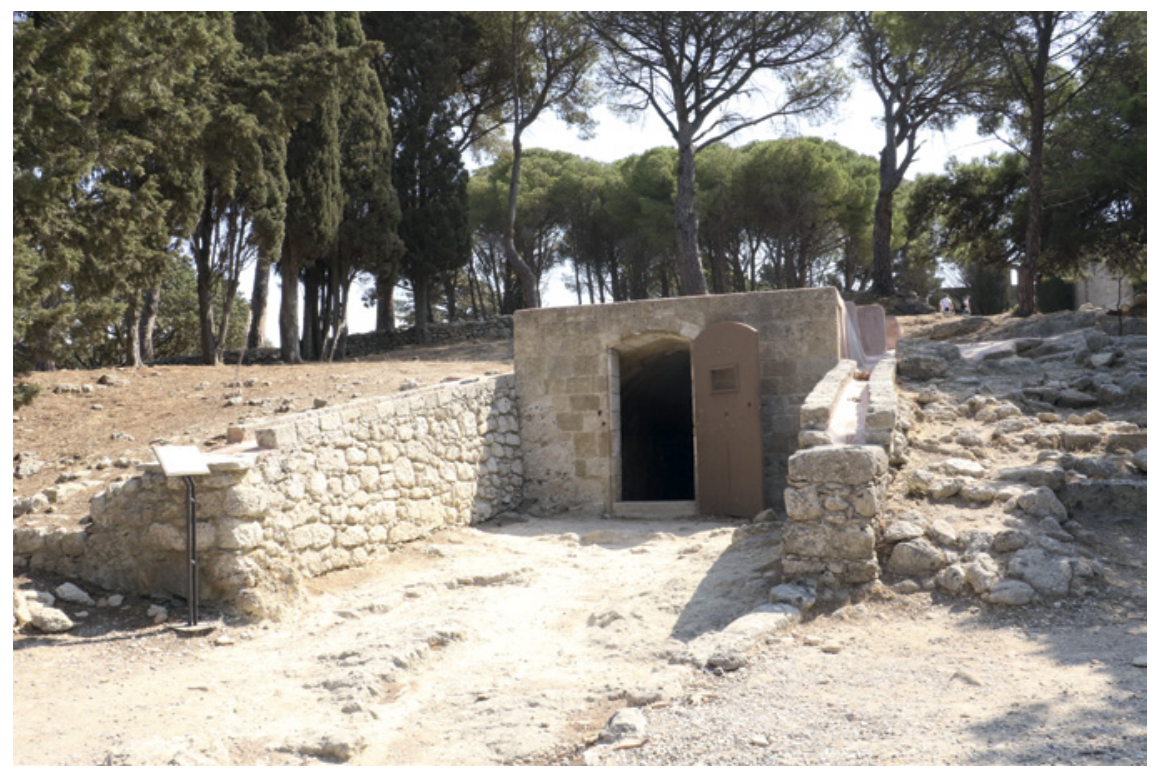

FIGURE 84A The church known as St. George Chostos, Mt. Phileremos. West entrance

have an apse and is surmounted by a barrel vault (Figs. 84a, 84b). The modern dedication to St. George relied on the identification of the saint in the lower register of the eastern wall and does not seem to correspond to the actual patron saint of the chapel. ${ }^{24}$ Its iconographical programme is extant on the side walls, the east wall, and the vault. On the south wall it consists of scenes with Knights and supplicants with their patron saints (Fig. 85). On the north wall, a Deesis is depicted at the eastern end, followed by the Archangel Michael stabbing the devil and two supplicants kneeling. Behind them, groups of laymen are shown under the protective mantle of patron figures, some of them female, in the type of the Mater misericordiae (Fig. 86). Seven scenes of the life of the Virgin are seen on the south part of the vault and seven episodes of the Passion on the north part. Christ Enthroned with Sts. Peter and Paul, two other saints, and at least one donor are depicted in the lunette of the eastern wall; one is bearded, wears a black robe with the hospital's cross, and kneels in front of the first saint on Christ's left. A second layer of painting that was identified in the

24 Luttrell supports an attribution to the Virgin; Luttrell and O'Malley 2019, 68. Ferraris di Celle writes that according to local legends the cult of the Phileremos emerged in this subterranean church; Ferraris di Celle 1988, 87. 


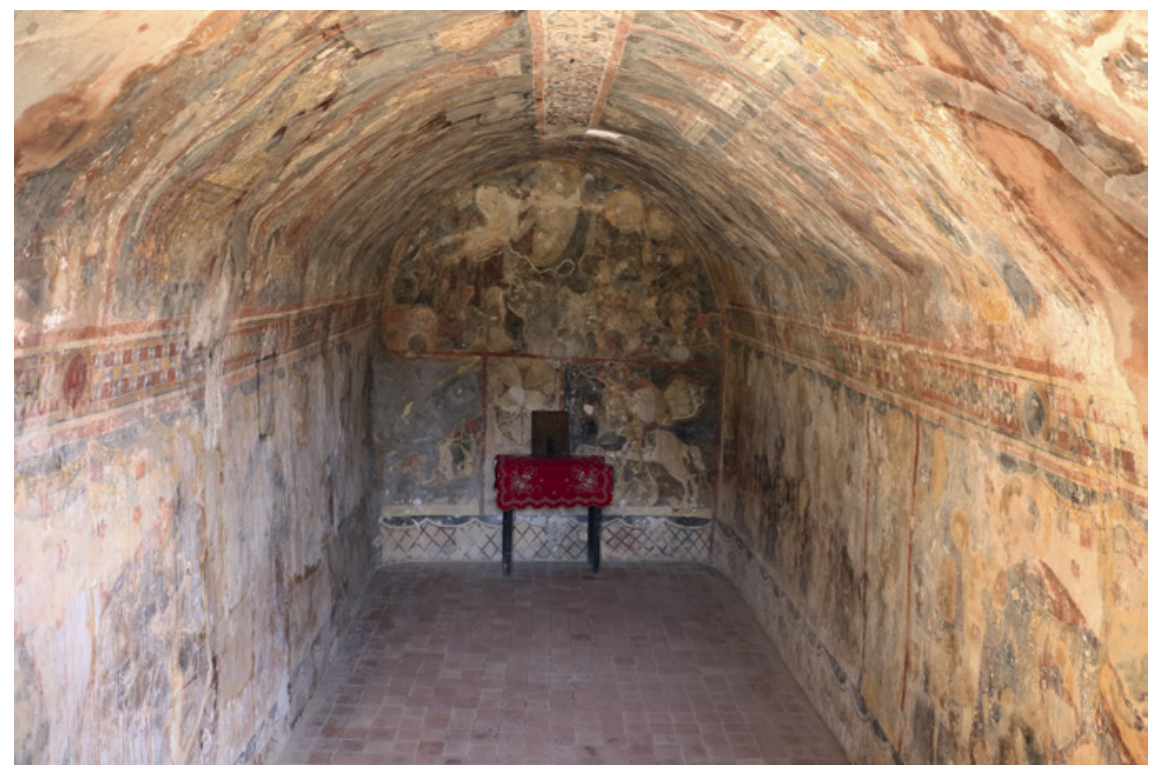

FIGURE 84B The church known as St. George Chostos, Mt. Phileremos. Interior view to the east

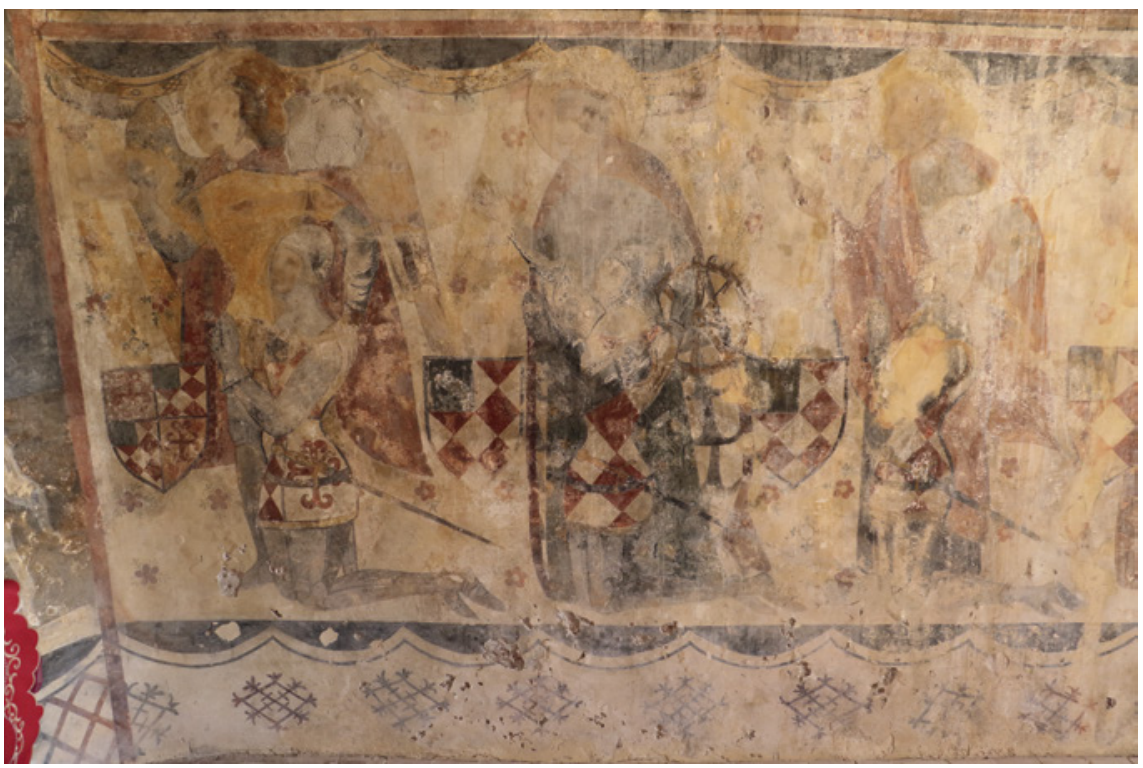

FIGURE 85 The church known as St. George Chostos, south wall, detail with knights and their patrons 


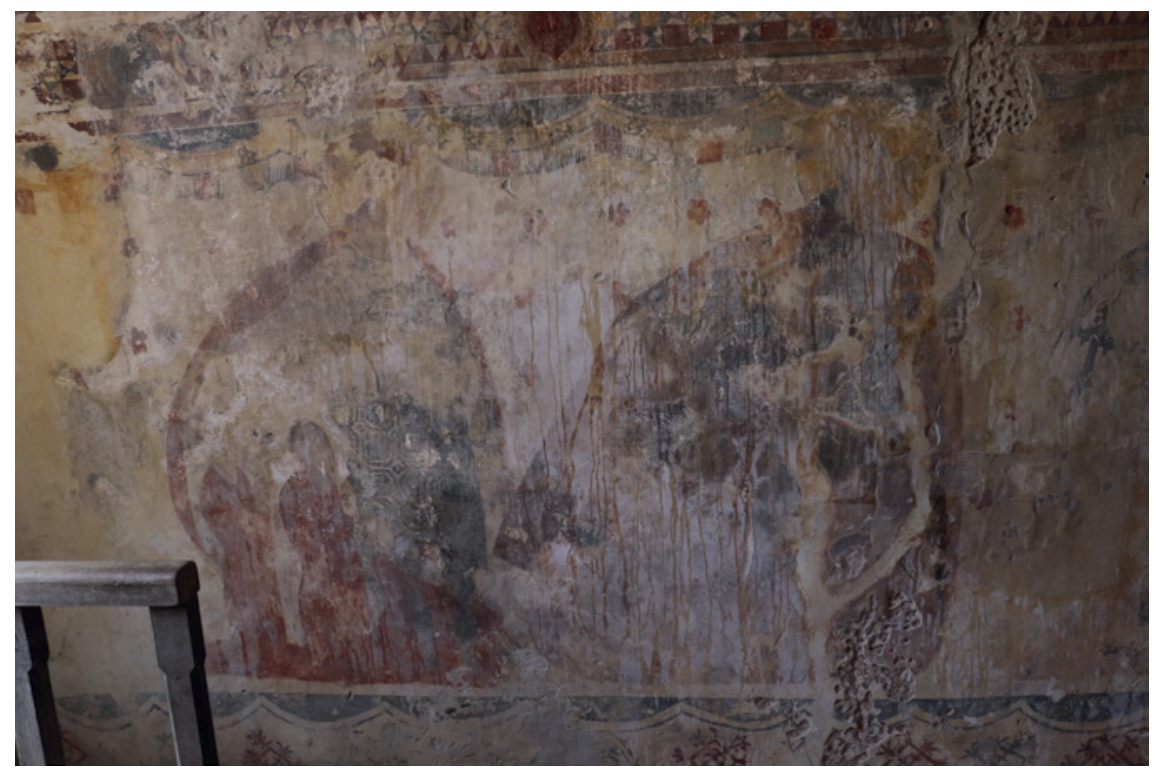

FIGURE 86 The church known as St. George Chostos, north wall, detail with supplicants and their patrons in the type of the Mater misericordiae

lunette was deemed to be contemporary with the overlying one and most likely the result of corrections or alterations made by the painter while working. ${ }^{25}$ In the lower zone there are: St. George on horseback killing the dragon at the right; a red cross on a white background in the middle; and an unidentifiable scene to the left (Figs. $87 \mathrm{a}, 87 \mathrm{~b}){ }^{26}$

The paintings, which bear many signs of overpainting, were restored in 1939 by Ricardo de Bacci Venuti, a Florentine painter and restorer. ${ }^{27}$ Their characteristic mixed, eclectic style, combining Western and Byzantine elements, could be attributed to either a Greek or a Latin master, but the poor state of preservation, due to humidity as well as their retouching, has impeded further analysis. ${ }^{28}$ The dating of the frescoes has been a matter of discussion.

\section{Livadiotti 1996, 266.}

26 For an extended treatment of the frescoes, see Ferraris di Celle 1988, 115-147. See also Rottiers 1830, 361-374; Rottiers 1828, pls. 61-66; Schlumberger 1911, 211-216, where he publishes the watercolour drawings of $1860-1870$ by the architect Auguste Salzmann; de Vaivre 2004, 919-943; Bacci 2017b, 112-115.

27 Livadiotti 1996, 265-266; Ferraris di Celle 1988, 10o; de Vaivre 2004, 927-928, 934.

28 On the eclectic style in Rhodian painting, see Kollias 2000; Kollias 2005, 123-129; Archontopoulos 2010, 233-238. The available 19th-century depictions by the painter P. J. Witdoeck, published in Rottiers' work, are problematic, because some do not 


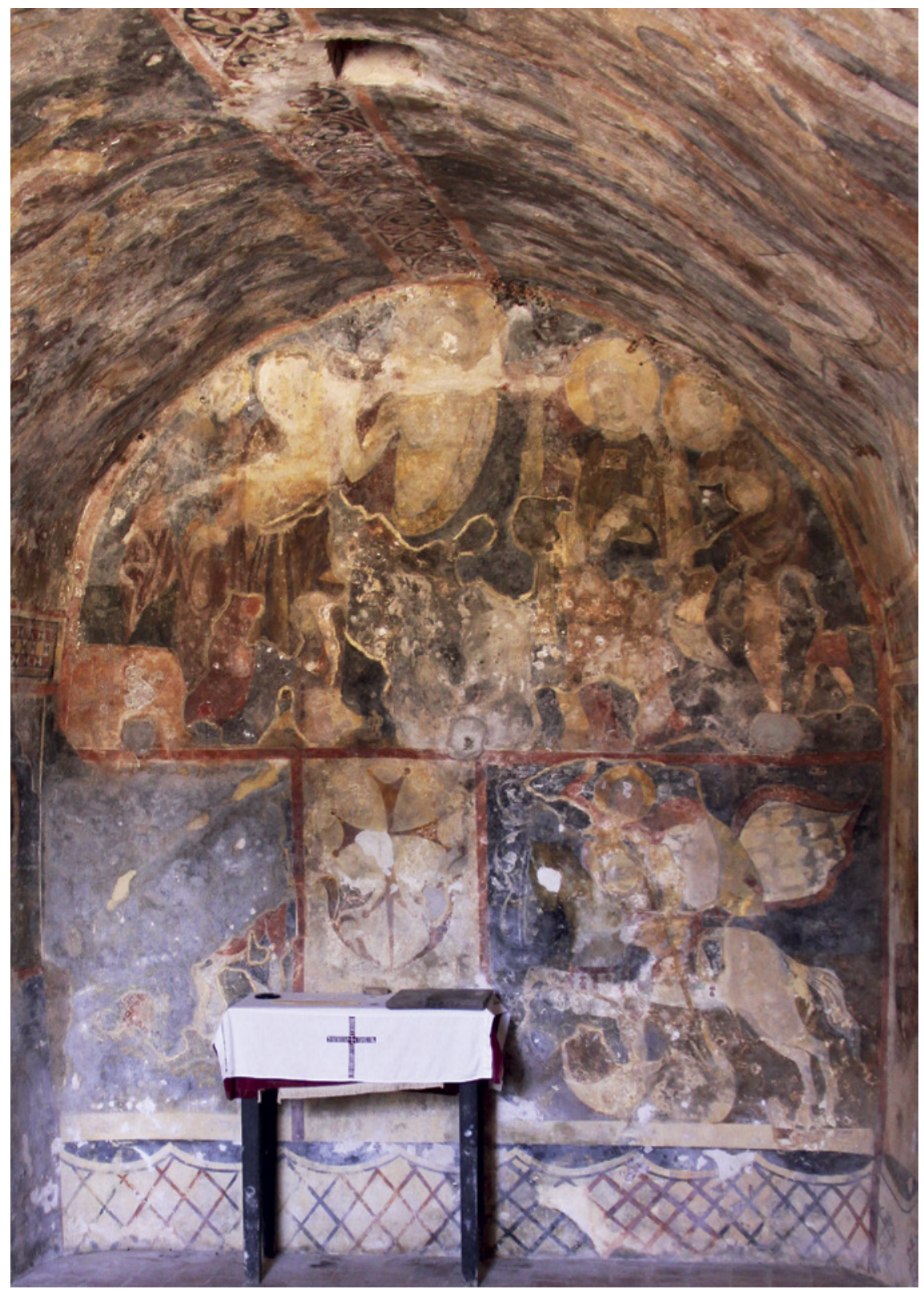

FIGURE 87A The church known as St. George Chostos, east wall 


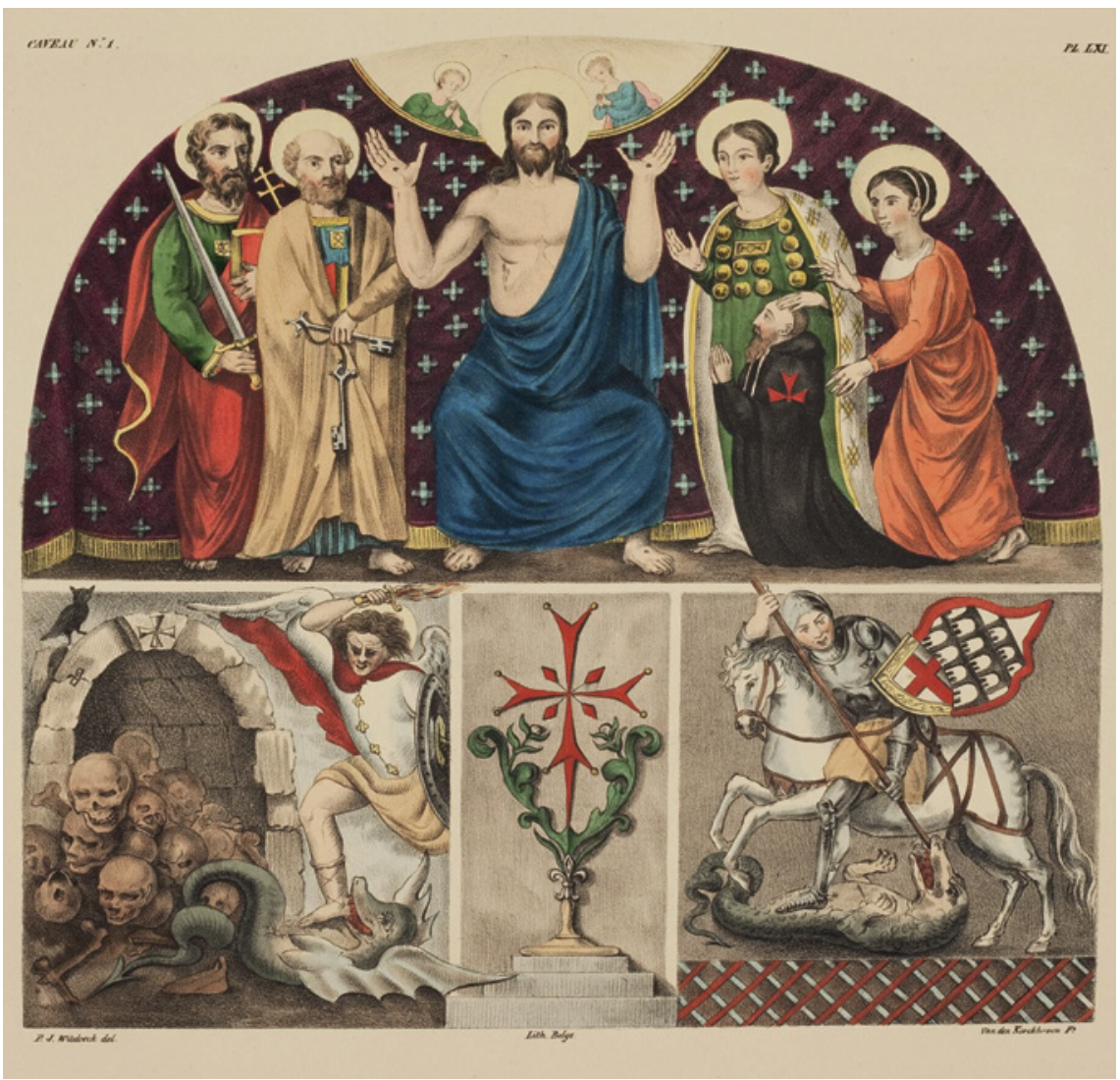

FIGURE 87B The frescoes on the east wall, 1828, lithograph after P. J. Witdoeck

Iconographical elements on the side walls, in particular the type of Our Lady of Mercy protecting the faithful under her outspread cloak, and the type of armor of one of the figures, agree with the identification of the coats of arms as those of the Nantouillet family and a dating ca. 1367, when Regnault Nantouillet passed by Rhodes and possibly commissioned the works as a sort of ex voto on behalf of himself and members of his family. ${ }^{29}$ This is also backed up by the date 1447 that appears among the numerous $15^{\text {th- }}$ and early 16 th-century graffiti, in Western script, on the paintings of the vault and serves as a terminus

correspond to the present state of the paintings, a fact evident even when comparing these sketches with the watercolours by Salzmann, which are more reliable (see note 26 above).

29 Bacci 2017b, 113; de Vaivre 2004, 931-943. See note 6 above. 
ante quem. ${ }^{30}$ On the other hand, the presence of the arms of Aubusson next to the first kneeling knight on the south wall, as well as stylistic and iconographical details in the episodes of the life of the Virgin and of the Passion, hint at a date in the late 15 th century or the early $16 \mathrm{th}^{31}{ }^{31}$ these elements, and especially the arms of Aubusson, ${ }^{32}$ may have resulted from overpainting or a second layer of decoration. The overall present appearance of the chapel points to a funerary use, which would certainly be associated with the indiscernible donor/s depicted in the lunette.

The presence of Mariological scenes and the Western graffiti are in keeping with the popularity of the Phileremos' cult, but the dating, use, and connection of this underground chapel with the Hospitaller church and, subsequently, the miraculous icon is not clear. ${ }^{33}$ There had been a Byzantine church on top of it, traces of which were discovered by Maiuri during the excavations; it was revealed then that the floor of the chapel was lower than the frescoes and that there must have been a cistern collecting spring water from the underly-

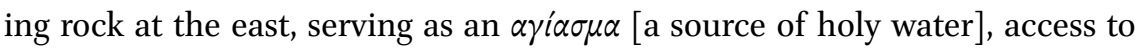
which would have been provided by the still extant opening in the ceiling. ${ }^{34}$ It is unknown when the overlying church was destroyed, but certainly after its destruction the character of the crypt changed, perhaps at some point after 1350,35 and its decoration was commissioned subsequently. This would mean that works on the chapel were more or less contemporary with the first Hospitaller single-aisled church, built in the first or second half of the 14th century, and, having in mind the private character of the chapel, it is logical to assume that the references to the Phileremos church after the 14th-century concern these constructions erected by the Hospitallers.

The miraculous icon of the Phileremos Virgin was allegedly a work by the hand of St. Luke, ${ }^{36}$ falling in an extremely popular category of cultic icons of the

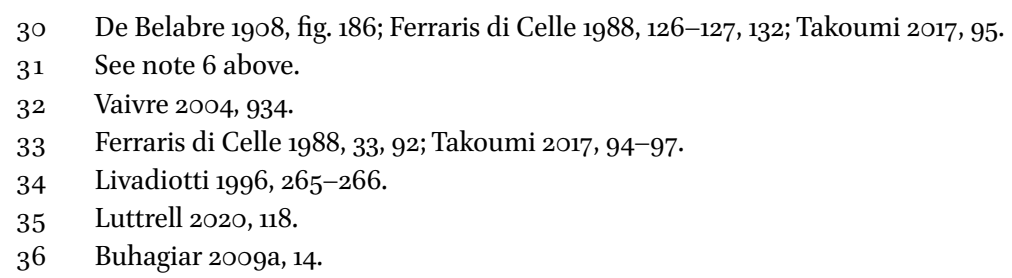


period. ${ }^{37}$ The Evangelist, a doctor and a painter, had been established as the executor of the true portrait of the Virgin, during her lifetime. ${ }^{38}$ The pilgrims at Rhodes were aware of the Lucan attribution: Pierre Barbatre (1480) attests that the icon was one of the images that St. Luke had painted, ${ }^{39}$ and Wolfgang Zillenhart (1495) repeats that, "there is an image of Our Lady, painted by St. Luke, which performs great signs." ${ }^{\prime 0}$ As usual, pilgrims' narrations include inconsistencies. Strangely enough, during his trip in 1462 William Wey reports that the icon of the beatissime Marie was executed by John the Evangelist at Patmos and that it was later painted by others, but the icon of Phileremos was the first one made to honour the Virgin. ${ }^{41}$ The link with John is somewhat puzzling, as Wey's text incorporated the information concerning the first-ever execution of the Virgin's portrait. Could this be a misunderstanding on his part concerning the specific identity of the Evangelist, or could it be supposed that the legend of the evangelical icon was - to an extent-further localised, since it was well-known that John had resided and written the Apocalypse on the nearby island of Patmos, thus ascribing the work to him? It is evident from the sources, though, that the Lucan attribution, should it have been known to the pilgrims, is a clue that they do not seem to consider important or necessary enough to mention.

The advent of the icon at Mt. Phileremos was shrouded in the mist of legend. According to a magistral bull of 1497 , it had miraculously traveled to Rhodes during the rule of an Emperor Leo the "Heresiarch," probably Leo III the Iconoclast (717-741). ${ }^{42}$ It was also said that it had been worshiped in the Holy Land as the Madonna of Bethlehem..$^{43}$ Another story relates that a nobleman from Rhodes who wanted to end his life reached the site with the aim of falling from the mountain, but the apparition of the Virgin stopped him; after that, he decided to live as a hermit, built a small chapel, and, wanting to endow

37 On Lucan icons, see Bacci 1998; Bacci 2004a, 423-452. On miraculous icons, see Cormack 1988, 55-6o; Belting 1994; Oikonomides 1991, 35-44; Ševčenko 1991, 45-57; Lidov 200o, 47-57; Pentcheva 2006.

38 On the legend of Luke as an icon painter, see Bacci 1998, 33-96.

39 “[... une des ymages que monseigneur sainct Luc paingnist;" Pinzuti and Tucoo-Chala $1972-1973,15^{8-159}$.

40 "[...] ist unser frawen bild, hat sant Lucas gemalt, tut grosse zaichen;" Gebele 1932$1933,114$.

41 " [...] ibi est ymago picta beatissime Marie, quam pertraxit sanctus Johannes Evangelista quando erat in Patmos insula cl. miliaria a Rodys, que postea erat ab aliis picta; et est prima ymago que facta erat ad honorem beatissime Marie, et facta sunt ibi multa miracula;" Williams 1857, 99.

42 Luttrell 1989, 13. The document has been published; see Tsirpanlis 2012, 220-229.

43 Buhagiar 2009a, 14. 
it with an image that bore the features of the blessed Virgin, he brought an icon from Jerusalem that he knew was thought to have been a work of Luke. He led a long and pious life on the mountain, and his hermitage attracted many pilgrims and fame to the sanctuary. ${ }^{44}$ Conforming to a popular topos in legends concerning miraculous icons was another version, according to which, during many days of fog and darkness in the area, the inhabitants saw a bright light on the mountain; when they searched for its prodigious source, they found the icon and erected a sanctuary on the very spot. ${ }^{45}$

The Hospitallers had worshipped the Virgin as their perpetual supporter and protectress ${ }^{46}$ ever since their founding at St. Mary of the Latins in Jerusalem. It is no surprise that soon after they established their rule on Rhodes they became actively involved with the sanctuary housing the miraculous icon of Our Lady of Phileremos. This choice must have also been connected with the history of their occupation of the island: it was at Phileremos that they had achieved one of their first, big victories. Indeed, pilgrims often narrate how the Knights fought the infidels or the schismatic Greeks at the site-and these events often highlighted the Order's desired messages and symbolism. ${ }^{47}$

From the beginning of Hospitaller rule on the island, the situation concerning the aspects of the veneration at the church by Greeks and/or Latins is unclear. The legends connected with the icon suggest that the cult was already established in 1309, but no Greek sources documenting this have been discovered. The Order's actions toward exercising some control very early on attest to the above, as is evidenced by the Nantouillet frescoes, which would presuppose an active Latin religious presence. Ogier d'Anglure's testimony shows that the Hospitallers had already established a pilgrimage to the icon and testifies to the shared devotion toward it; ${ }^{48}$ the addition of the two chapels in the mid15th century was, perhaps, an answer to the increasing flow of pilgrims and the need to meet the cultic and liturgical demands of larger groups. Although the icon did not belong to the Common Treasury, it seems that the cult was controlled by the Knights from the 14 th century. ${ }^{49}$

\footnotetext{
44 Sommi Picenardi 1900, 215.

45 Calamai 1993, 77.

46 Luttrell 1993, 8o-83; Zammit Gabarretta 1983, 249-266.

47 In pilgrims' narratives, the castle at Phileremos is connected with the painstaking and long struggle of the Order to occupy the island. See indicatively Ogier viII d'Anglure (1395-1396), Dietrich von Schachten (1491), and Melchior zur Gilgen (1519); Bonnardot and Longnon 1878, 91-93; Röhricht and Meisner 188ob, 217; Gilgen, "Pilgerfart," 48.

48 Since, after 1309, the Greeks of Rhodes technically became Uniates, there would be "no canonical problem of conflicting communions;" Luttrell 2020, 117.

49 See pp. 194-195 above. See also Buhagiar 2017, 68.
} 
The pilgrims' visits to Phileremos and their mentions of the site increase dramatically after 1460 , and it is often the place first remarked upon about the island; its location on the mountain made it visible from the sea and recognizable to the sailing groups, ${ }^{50}$ making its inclusion in the seafarer's prayer known as the Sante Parole only reasonable. ${ }^{51}$ Indicative of Our Lady of Phileremos' special association to the seafarers are the words by which it is described by the German Ulrich Leman (1472-1480): "There is a church, named Our Lady of Phileremos, on a mountain, where lies our dear Lady of Mercy, who works great miracles and is a big help in times of need for the traveling ships at sea, and they pay great reverence to her during their navigation."52

By 1480, the Madonna seems to have been well-established as a protectress of navigation. On his way back from the Holy Land, an anonymous pilgrim reports that all the passengers and crew of the ship took an oath to visit the Phileremos, because her help at the time was necessary against the contrary wind that had kept the ship off course for four days and four nights..$^{53}$ Likewise, while trying to escape from 44 battleships off the coast of Turkey, Jehan de Tournai (1488-1489) and the rest of his group promised a candle to the Virgin of Phileremos, and immediately a strong wind arose; when they reached Rhodes they made good on their pledge, pilgrims and mariners alike. ${ }^{54}$

The association of the hopeful and pious visitors with the Phileremos Madonna proved to be more than just a swift stop in their itinerary to the Holy Land: it would become incorporated into their belief system and eventually even perceived as a crucial moment in their devotional experience associated with pilgrimage. In the stream of his detailed narrative, Alessandro di Filippo Rinuccini (1474) gives an unparalleled example. While visiting Mt. Quarantania, near Jericho, an English pilgrim was brutally attacked by three men. In this dramatic instance, it was the Phileremos Madonna whom he addressed for help and "managed to escape, making a vow to Santa Maria di Filermo;" when in Rhodes, they found themselves together at the shrine to venerate the icon. ${ }^{55}$

50 Louis de Rochechouart (1461), Bishop of Saintes, spotted it while sailing: "Circa horam octavam, die vigesima junii, et ad manum dextrarn, vidimus ecclesiam Beate Marie de Palerma, alias Philerma;" Couderc 1893, 234. The same for Jan Hasištejnsky z Lobkovic (1493); Strejček 19o2, 37.

$5^{1} \quad$ Bacci 2004b, 243 .

$5^{2}$ " [...] da ist ain kilch, die haist vnser frow von Vilerm, litt vff aim berg, da ist vnsa liebi frow genedig, die tut fast grossi wonderzaichen, ist ain grossi nothelfferin im mer vnd die schiff, die im mer da fúrfarent, die tund ir grossi reuerentz alwäg am fúrfaren;" Reininger 2007, 3 .

53 Schefer 1882, 110-111.

54 Blanchet-Broekaert and Péricard-Méa 2012, 270-272.

55 "Costui iscampò facendo boto a sancta Maria di Filermo;" Calamai 1993, 69. 
Concerning the practical issues of veneration, evidence pointing to the location of the icon in the church appears in the late 15th century. In 1471 Anselmo Adorno mentions that the small church where the icon of the Virgin worked many miracles stood on top of a small cave, perhaps alluding to the crypt of St. George Chostos nearby. ${ }^{56}$ After delivering the aforementioned legend of the icon emitting bright light, Alessandro di Filippo Rinuccini reports that the inhabitants:

[...] built the church to honour the glorious Virgin Mary and placed the said image in a small arched chapel, at the side of the chapel where lies the altar of the Assumption of the Virgin Mary and where the mass is celebrated in reverence of the Virgin, on the left side of the said church. [...] Next to the main chapel of this church, on the left hand, there is another chapel decently decorated. ${ }^{57}$

This would mean that the icon was placed for veneration in the recently built north chapel. The setting changed when Aubusson constructed his two chapels, where there was a semi-circular niche still standing in 1900, which Sommi Picenardi saw as the setting for the icon. ${ }^{58}$

The site-specific experience of the icon's veneration was in keeping with late medieval patterns of image worship; visitors would offer candles, celebrate mass, and marvel at the icon and its votive offerings: "Her image, which is painted on a panel and then adorned with golden cloth and many images and ships made of silver and lights and various images of wax."59 Additionally, material indicators of the many miracles performed in the holy shrine were exhibited. One of them was a rope with which an Ottoman tried to hang a Greek merchant; he had used three ropes, but all of them broke after the intercession of the Virgin of Phileremos, to whom the merchant addressed his prayers. The Ottoman, amazed by the miracle, let the Greek free, and the latter made a pilgrimage to the Virgin and dedicated one of the ropes, which was hung as a

56 "Juxta, quem locum super uno parvo cavo stat ecclesia parva, in qua ymago Nostre Domine multa miracula fecit;" Heers and de Groer 1978, 366 .

57 " [...] hedificorono la chiesa in honore della gloriosa Vergine Maria, collocando detta ymagine in una picciola chappella archuata, al lato alla chappella dove è l'altare della assunptione della Vergine Maria et dove si celebrano le messe a sua reverentia nella parte sinistra di detta chiesa. [...] Al lato alla chappella magiore di questa chiesa, in sulla mano sinistra, è constructa e murata un'altra picciola chappella decentemente ornate;" Calamai 1993, 77 .

58 Sommi Picenardi 19oo, 211.

59 "La sua imagine, che in essa si truova dipinta in una tavola et poi addorna di drappo d'oro et molte ymagini et navi d'argento et torchi et diverse ymagini di cera;" Calamai 1993, 77 . 
token of the prodigious event. ${ }^{60}$ The collection also included three frogs that had been emitted from a possessed man, shown to Greffin Affagart in 1519. ${ }^{61}$ This miracle may have been typical of the Virgin's powers or may have become famous, as the wife of a Greek priest had also been cured from an evil spirit, which she vomited in the form of a live frog. ${ }^{62}$ Connected with these objects, occasions when the icon had miraculously interceded with its visitors were propagated, such as the story of a young couple whose parents were opposed to their marriage - they found the opportunity to meet in the church and at the moment of their sacrilege were blasted on the very altar. ${ }^{63}$

For the Hospitallers, the icon of the Madonna of Phileremos becamealong with the Baptist's hand-their most prized possession: they found in her a symbol for their struggles and ideals, as well the emblematic manifestation of their perpetual protectress. ${ }^{64}$ The Virgin's powerful intercession in the Ottoman siege of $148 \mathrm{o}$, when the miraculous apparition of the Cross, the Virgin, and the Baptist in the decisive battle secured victory for the Order, became famous through the work of Guillaume Caoursin, Obsidionis Rhodiae urbis descripti, in which the event was also illustrated (Fig. 88). During the siege, the icon had been transferred to the Conventual church inside the city, so as to be protected from the attack and to enable its veneration by the people. ${ }^{65}$ There it served as the palladium of the besieged, a fact evidenced by the penitential procession to its temporary setting led by the Master Pierre d'Aubusson, in order to express his gratitude for the Virgin's succor after a harsh battle at St. Nicholas' tower. ${ }^{66}$ In commemoration and gratitude of her powerful intercession, Aubusson built the church of Our Lady of Victory at the east end of the borgo, near the sector of the langue of Italy, where the siege's decisive battle had taken place. ${ }^{67}$

The same practice of relocation was repeated in 1513, again under Ottoman threat. During the siege of 1522 , the icon was deposited in the church of St. Mark (it is not certain whether St. Mark had passed again to the Greeks by then or was still serviced by the Franciscans). After a fire attack, from which it miraculously escaped damage, it was transferred to the church of St. Catherine in the borgo, a more secluded location. It is not clear which of the churches

\footnotetext{
6o English Anonymous (148o-1526); Brefeld 1985, 152 .

61 Chavanon 1902, 39. See also Gumppenberg 1672, 89 o.

62 Buhagiar 2009a, 14.

63 Sommi Picenardi 1900, 215.

64 Buhagiar 2009a, 13-14.

$65 \quad$ Bosio 1630, 398.

66 Ferraris di Celle 1988, 27-29.

67 See pp. $184-185$ above.
} 


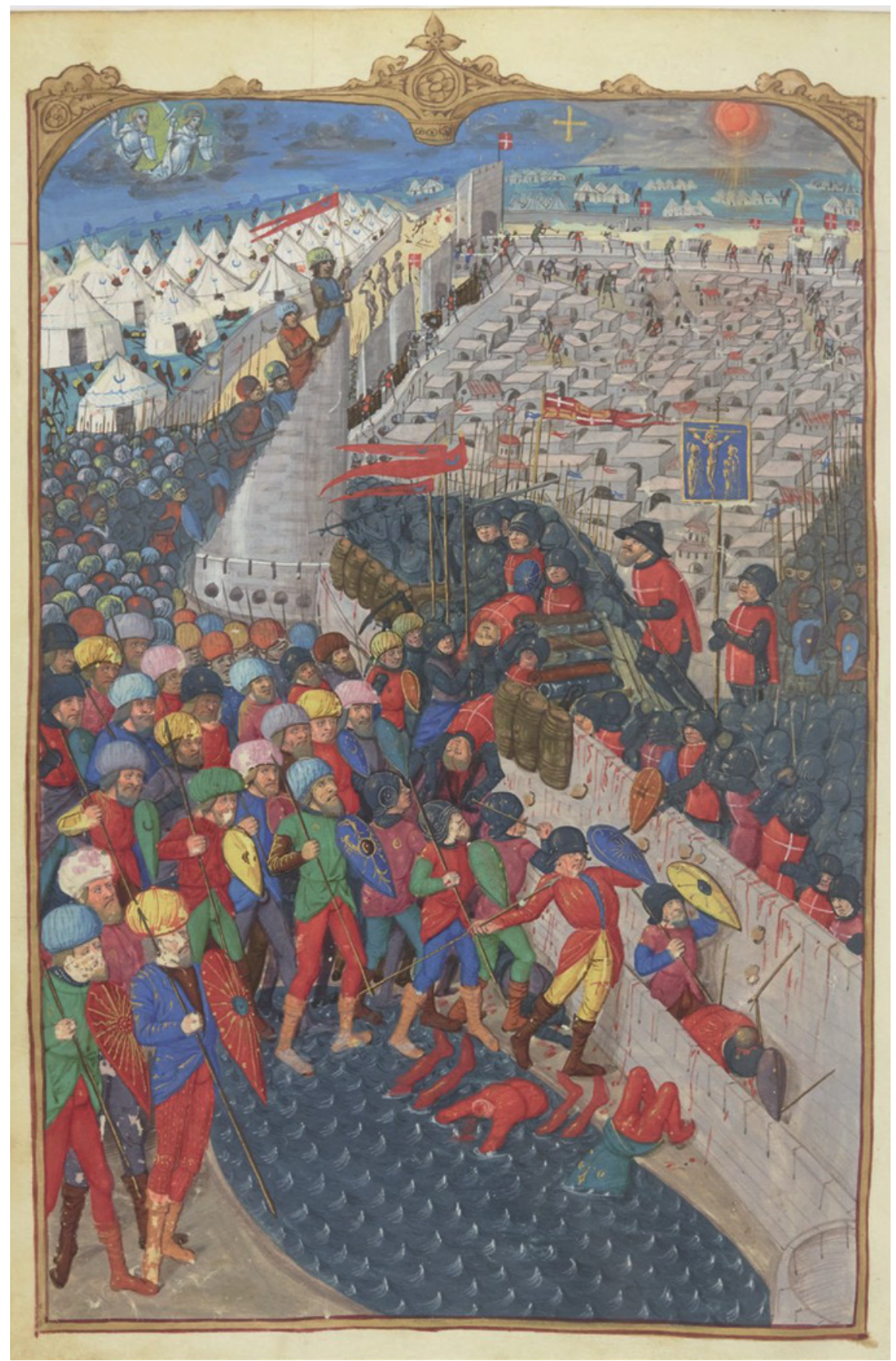

FIGURE 88 The decisive battle of 1480 at Rhodes with the miraculous apparition of the Cross, the Virgin, and the Baptist, ca. 1483, manuscript illumination. Paris Ms. Lat. 6067 
dedicated to the female saint this was; at that time the church subsequently known as Ilk Mihrab - after its conversion into a Muslim place of worshipwas dedicated to St. Catherine. ${ }^{68}$ After the capitulation to the Ottomans, the Greek Nicolaus Metaxi saved it and took it on board the carrack Sant'Anna, the main ship on which the brethren left Rhodes on January 1st, 1523, where it was placed in a chest along with other major Hospitaller relics. From now on, the Order certainly had complete control over it. ${ }^{69}$

For the Hospitallers, expressions of Marian piety at Rhodes were manifold. ${ }^{70}$ In the town, apart from Our Lady of the Castle (the Latin cathedral in the collachium), Our Lady of the Burgh, and Our Lady of Victory, there is evidence of at least six other, no longer extant churches dedicated to the Mother of God. However, only the panel of the Phileremos seems to have been appropriated by the Knights as a miraculous Marian icon. There cannot be certainty about how and by whom the icon was handled: the testimonies that place it in St. Mark and in St. Catherine in 1522, as well as the above information concerning Nicolaus Metaxi, which is based on his own testimony and cannot be substantiated, reveal that the Greeks were also involved.

This idea is further connected with the handling and fate of two miraculous Byzantine icons that, although kept in the town, were never mentioned by the pilgrims, possibly due to a lack of information from the brethren. ${ }^{71}$ These were the icons of the Virgin Damaskini and Eleimonitria now kept in the Greek Catholic Church of the Virgin Damaskini in Valletta (Figs. 89, 90). At Rhodes, they were owned by Greeks and housed in two homonymous churches, the first one on the south side of the borgo, in the Aragonese sector, and the second one just outside the walls, near the English sector. ${ }^{72}$ Archival documents from Malta that were published in 1988 attest to the traditional Greek ownership of the icons and their churches based on the jus patronatus; specifically, for many

68 Ferraris di Celle 1988, 33-34; Sommi Picenardi 190o, 216; Archontopoulos 1986, 85-100.

69 Buhagiar 2009a, 15-16.

$70 \quad$ Bacci et al. 2017, 97-101.

71 Moreover, in the countryside, an icon of the Madonna bearing Aubusson's coat of arms in the church of the Holy Cross at the village of Apollona reveals a connection with a miraculous icon there, documented by Cristoforo Buondelmonti (1417-1420); Bayer 2007, 20. The miraculous icon of Apollona was transported, along with the Phileremos, to the Order's castle at Pheraklos in 1513 for safe-keeping, due to imminent threat; see Phillips 2013, 15-16.

72 Tsirpanlis 1988, 199-200. Concerning the icon of the Virgin Damaskini, see Mitsani 2007, 433-444. Mitsani's proposed connection of the icon with a Latin chapel in Damascus and the Hospitallers inevitably comes into conflict with Calamias' claim of jus patronatus and raises the question of why the work would then pass on to the Greeks and not stay in the Order's hands. 


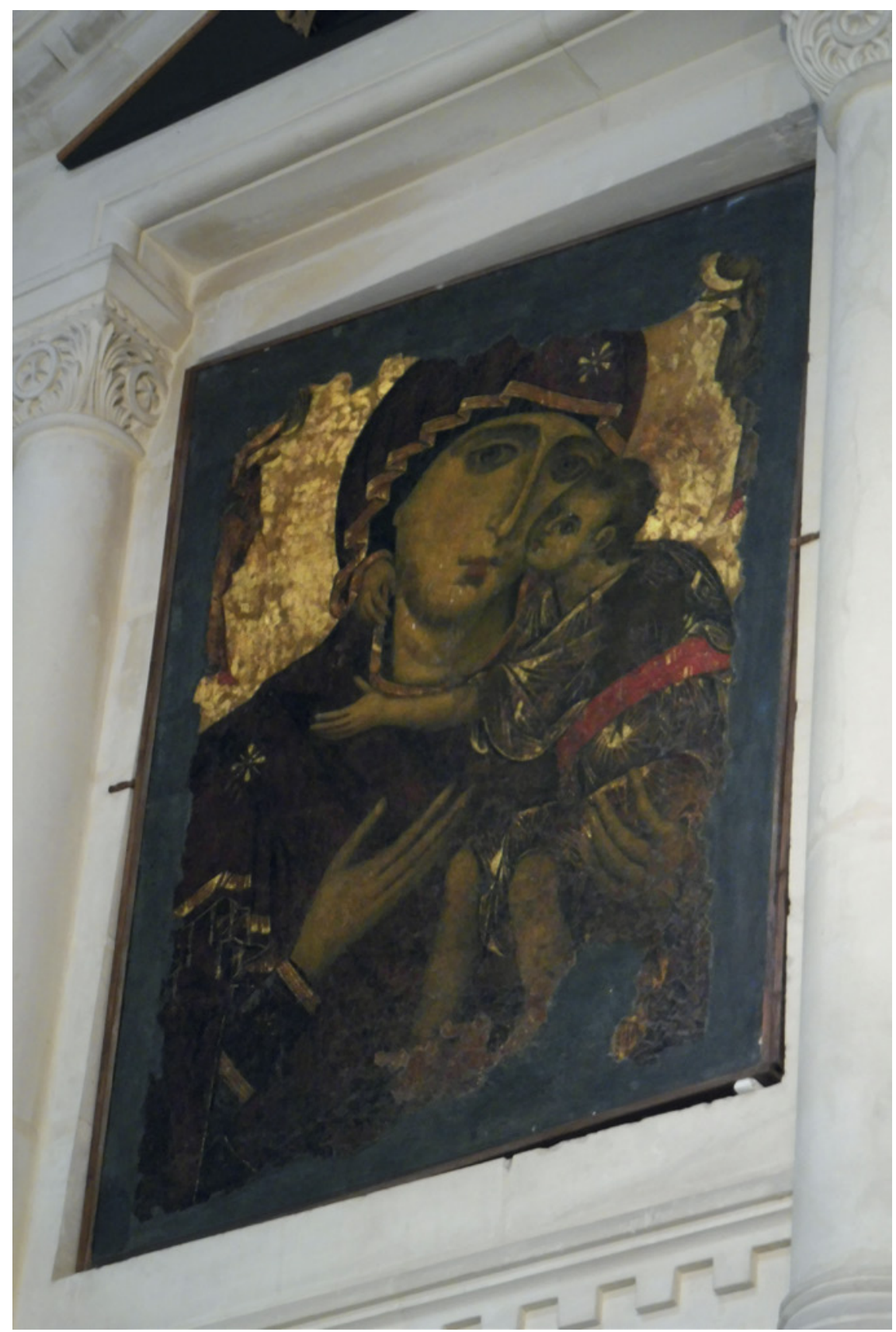

FIGURE 89 The Virgin Damaskini, 12th century (?), Greek Catholic church of the Virgin Damaskini, Valletta 


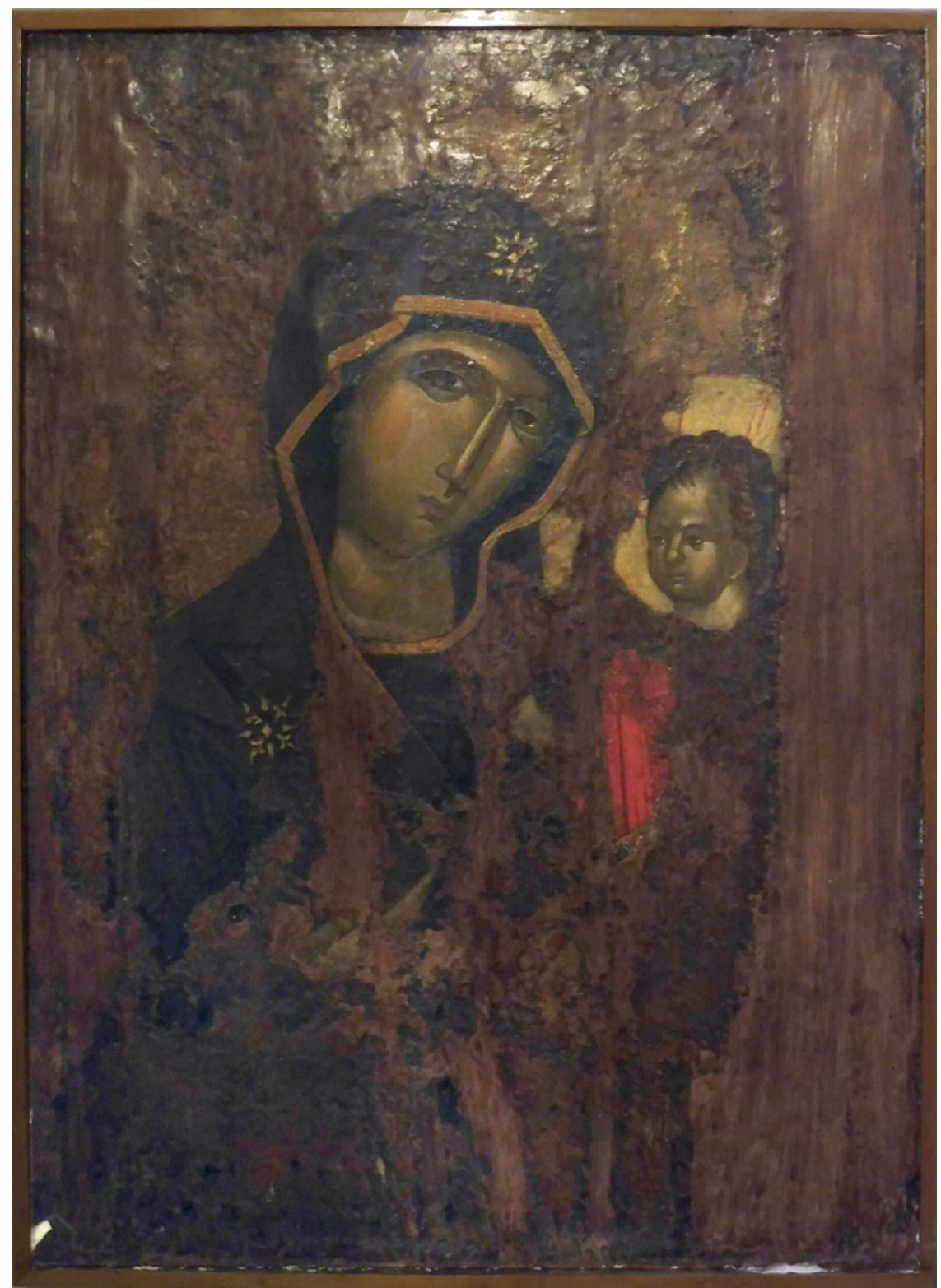

FIGURE 90 The Virgin Eleimonitria, 12th century (?), Greek Catholic church of the Virgin Damaskini, Valletta 
years before 1522 they had been owned by the Greek Calamias family. ${ }^{73}$ From the information inferred concerning their handling, it appears that their transportation to Malta was arranged by the Calamias family; that by order of the Master L'Isle Adam at Birgu, Malta, the Damaskini was given to a Greek Rhodian priest and was put in a church that eventually passed to the Greeks and bore the icon's name; and that the Eleimonitria ended up in St. Anthony's church, held by the Order. How and why the icons were removed from their rightful owners is not sure. However, the Order approved Ioannis Calamias' request for their return and recognized his ownership. ${ }^{74}$ Concerning Rhodes, there are no clues hinting that the Hospitallers interfered with the traditional cult of these Greek icons, in contrast with the miraculous Phileremos Madonna.

The Knights continued to promote the renowned cult of the Phileremos after leaving Rhodes. While they stayed in Viterbo, between 1523 and 1527, the exhibition of the icon in the collegiate church of Sts. Faustinus and Jovita, which was used as their provisional Conventual church, attracted crowds of worshippers, and the Hospitallers, upon leaving the city, left to the church the chest used for the transportation of the icon, as well an icon with the Virgin and Child, of the Hodegetria type, known as the Madonna di Costantinopoli. ${ }^{75}$ This was erroneously believed, according to tradition, to represent the Phileremos Madonna; its Creto-Venetian style may hint at a provenance from Crete, where the Hospitallers stopped on their way to Italy. ${ }^{76}$ However, it is also very possible that it came from Rhodes. According to two early 17 th-century testimonies, by Johannes Habermacher and Wolfgang Stockman, a Lucan icon of the Virgin that was kept at the Monastery of the Saviour or at St. Titus in Candia had been given (or was sold) by L'Isle Adam, when the Order passed by the island before reaching Italy. ${ }^{77}$ Since there is no evidence of a Lucan icon other than the Phileremos having been in the possession of the Knights, could it be possible that the Knights had copies of the Phileremos icon produced for distribution? This would have been a highly profitable move, along with the advantages

73 Tsirpanlis 1988, 197-236. Tsirpanlis published the documents (dated 1558-1559) concerning the request of Ioannis Calamias to the Order, in which he asked for the two icons to be returned to him.

74 Ibid. For the subsequent history of these two icons, see Chetta-Schirò, 1930; Chetta-Schirò 1932; Porsella Flores 1987, 12-23; Borgia 1999; Cutajar 1978b; Cutajar 1978a; Cutajar 1979b; Cutajar 1979a. Cutajar estimated that the two icons should be dated to the 12th century, an evaluation with which Buhagiar agrees; Buhagiar, 2018.

75 Ferraris di Celle 1988, 35; Ferraris di Celle 2009, 5 O.

76 Ferraris di Celle 2009, 5 o.

77 Schmid 1957d, 341; Schmid 1957b 176; Hemmerdinger-Iliadou 1967, 596-597. 
of amplifying the cultic competence of their revered image; the practice was well-established in the Middle Ages and reflected the belief that the replicas of the original image extended its power. ${ }^{78}$ The existence of a local workshop for the production of high-quality icons at Rhodes has been shown at least since the second half of the 14th century.79

When the Order reached Malta, the icon was placed in the church of San Lorenzo at Birgu, which served as the Convent's church. After the "Great Siege" of 1565 , the victory of the Knights against the Ottomans was again interpreted as a result of the Virgin's intercession, and October 8th, when the siege was terminated, was added to the liturgical calendar of the Hospitallers as the Feast of the Madonna of Victories, celebrating the same quality of the Phileremos as in $1480 .{ }^{80}$ Consequently, the first building of the new city of Valletta in 1566 was the church of Our Lady of Victories, an expression of gratitude to the Virgin, and the miraculous icon was transferred there. With the erection of the Conventual church in 1578, it was moved to the chapel of the Blessed Sacrament there, where it remained until Napoleon's invasion in $1798 .{ }^{81}$

It was then that the Master Ferdinand von Hompesch escaped from Malta, taking with him the hand of the Baptist, the relic of the True Cross, and the Phileremos icon, all stripped down from their precious furnishings by the French. The relics were transported to Russia; in 1799 the icon was located in the Voronzovsky palace chapel in St. Petersburg. ${ }^{82}$ On November 12th, an impressive procession was organized for the transportation of the three treasures to the imperial palace in Gatchina, and a feast for their translation was subsequently established..$^{83}$ Paul I commissioned a precious frame and riza for the icon, still extant, made of gold, diamonds, and sapphires, while its visible part, showing the face of the Virgin, was covered with polished glass (Fig. 91). The icon remained at the Winter Palace and was moved annually from $185^{2}$ to 1916 to Gatchina for the celebration of the feast of the translation. After the Bolshevik revolution, it was sent along with the other relics to Denmark, where the Tsarina Maria Feodorovna kept it and bequeathed it to Patriarch Antoniye of Kiev and Galizia, President of the Synod of Russian Orthodox Bishops in

\footnotetext{
78 See Belting 1994, 6, 14, 320, 342-348 and passim; Bacci 2004a, 423-452.

79 Acheimastou-Potamianou 2009, 199-214; Katsioti 2010, 143-145.

8o Buhagiar 2009a, 17-18.

81 Concerning the icon's setting in St. John's Co-Cathedral, see Scicluna 1995, 130-137; Buhagiar 2009a, 22-24; de Giorgio 2011, 58-63.

82 Piatnitsky 2000, 475. Concerning the icon's history in Russia, see Pjatnickij 1998, 14-25.

83 Piatnitsky 2000, 475. For information about the relic of the Baptist's hand, see pp. 58-61 above.
} 


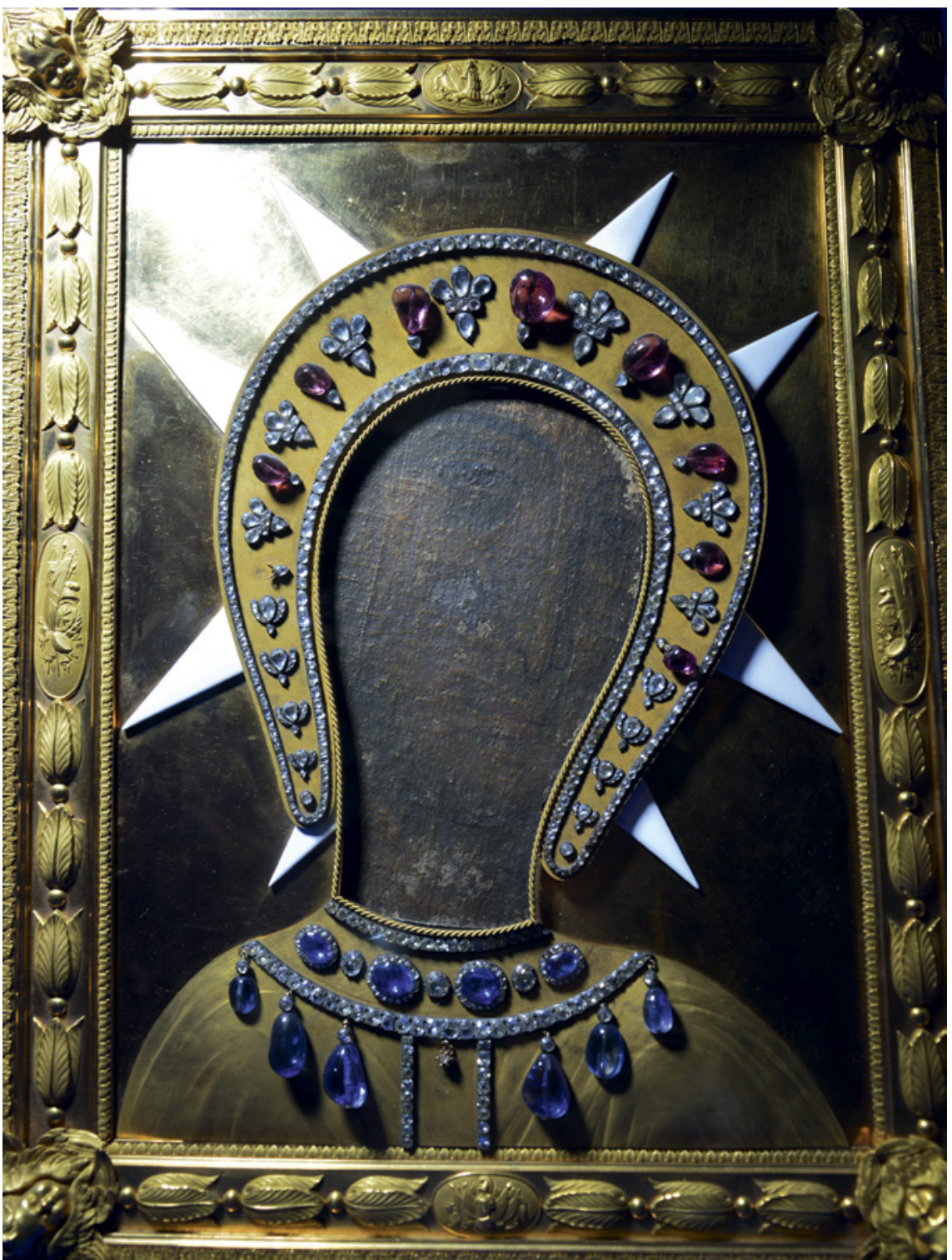

FIGURE 91 The Madonna of Phileremos with the riza, National Museum of Montenegro, Cetinje 
exile; ${ }^{84}$ subsequently, it was placed in the Russian Orthodox Church in Berlin and removed from there to the church of the royal palace in Belgrade. ${ }^{85}$ During World War II, it was secretly transferred to Ostrog Monastery in Montenegro, and in 1953 it was discovered there, along with the two other relics. ${ }^{86}$ Subsequently, it was kept secure by the government and deposited in the National Museum of Montenegro, Cetinje, in 1978. The identity of the work was unknown though; it was only in 1996 that it was identified by Giovannella Ferraris di Celle. Up until 2002 it remained in the institution's warehouse, and since then it has been exhibited in the museum's "Blue Chapel."

The icon of the Phileremos is considered to be a Byzantine work; in its present state, it is of small dimensions $(44 \times 36 \mathrm{~cm})$, but it consists of only a fragment of the original (Fig. 92). ${ }^{88}$ Its condition does not permit a safe conclusion concerning the iconographical type or dating. It is clear that the painted surface consists of two parts: the face and neck of the Virgin, which is painted on canvas, and part of her garments, which are painted on wood and develop around the face. This latter part bears many holes-especially in its lower section-which surpass 130 in number and must have been created by the attachment of numerous votive offerings over the years. ${ }^{89}$ The primary investigator of the work, Ferraris di Celle, examined the icon and proposed some hypotheses to deal with the possible interconnection of these two parts. ${ }^{90}$ According to her conclusions, the face could perhaps be dated to the 1oth-11th century, as part of a larger work of a Hodegetria of the type found at the church

$84 \quad$ Buhagiar 2017, 70.

85 Piatnitsky 200o, 475; Ferraris di Celle 1988, 38-41.

86 The discovery of the relics in 1953 seems to have been captured on film; Gagović 2012, 21.

87 For the history of the icon, see also Sbutega 2016.

88 Buhagiar gives the following dimensions for the icon at Rhodes and Malta, respectively: $141 \times 118$ centimeters, $100 \times 74$ centimeters; Buhagiar 2017, 61, 64. The measurements at Rhodes are given based on "the aedicule that contained it in the shrine, which the Master of the Hospital, Pierre d'Aubusson (1476-1503), rebuilt on the plateau of Mount Filérimos after the siege of 1480." For this information Buhagiar cites the article by Ferraris di Celle 2002, 29. Sommi Picenardi saw the niche that must have contained the icon and describes it as having a semicircular arch and a simple cornice, measuring $186 \times 118$ centimeters; Sommi Picenardi 1900, 211. The diminution of the icon at Malta is suggested by the dimensions of its marble tabernacle $(100 \times 74$ centimeters $)$ commissioned by the Master Jean Paul Lascaris (1636-1657) at the Conventual church of St. John at Valletta.

89 Ferraris di Celle 2009, 79 .

9o Idem, 103-105. This work is the main in-depth analysis of the icon at Cetinje after detailed examination of all of its layers. 


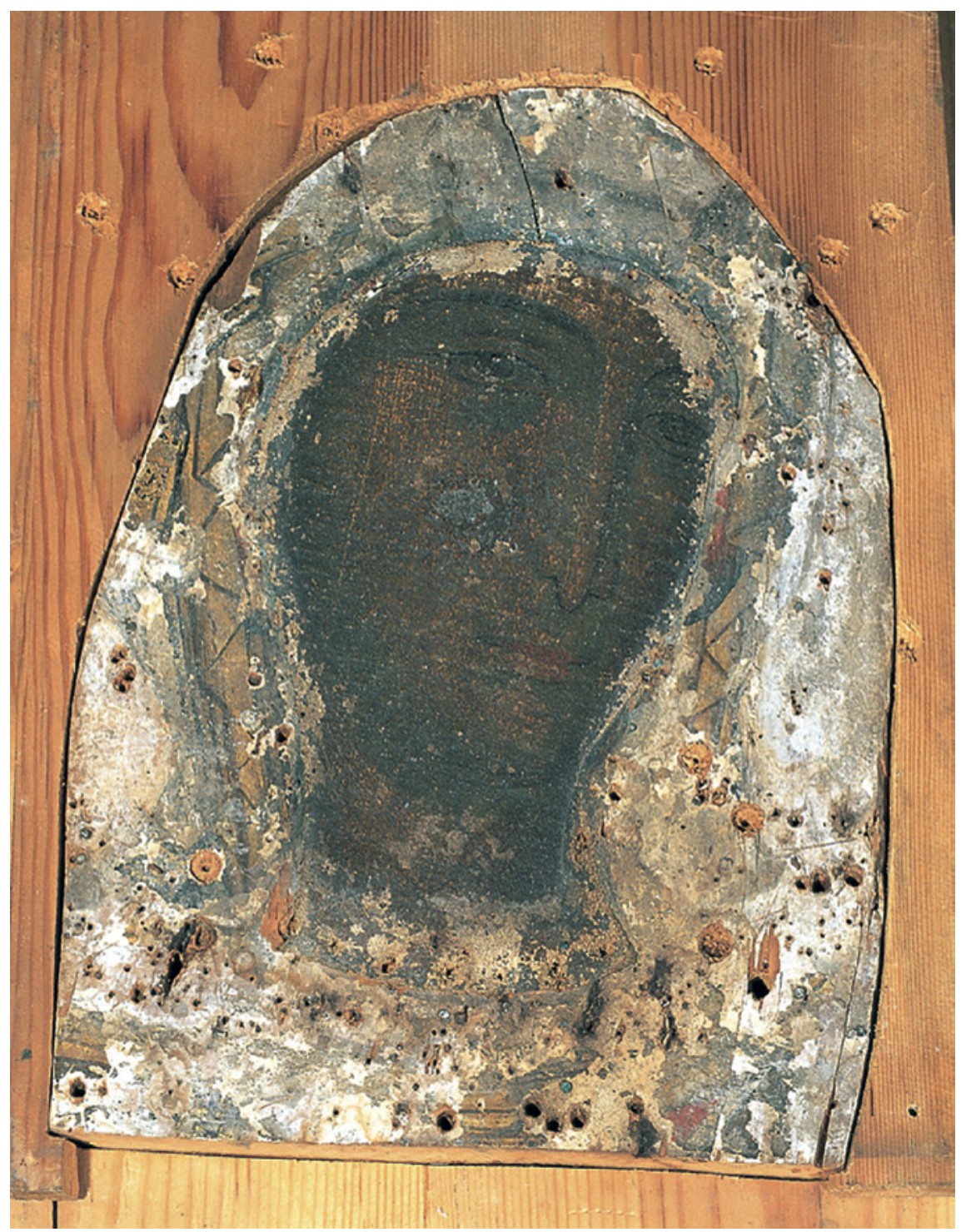

FIGURE 92 The icon of the Madonna of Phileremos uncovered, National Museum of Montenegro, Cetinje 
of the Dormition at Nicaea, and the surrounding painting to the late $15^{\text {th-early }}$ 16th century. ${ }^{91}$

How or when this icon reached Rhodes is unknown. Luttrell has investigated and summarized possible theories concerning the presence of an icon of the Virgin on Mt. Phileremos, but it cannot be sure when the specific work, now at Cetinje, came to be at Phileremos and as a miraculous icon. ${ }^{92}$ Connections with the presence of Constantinopolitan icons on the island, linked with Domenico de Alamania, Giovanni Corsini, and Emperor Manuel II Palaeologus, as well as with an active icon workshop, can only but remain speculative.

In its original form, the icon at Cetinje has also been thought to have been of the type of the Hagiosoritissa, in which the Virgin is depicted with both her hands extended out from her chest, similar to the pose she assumes in Deesis compositions. This hypothesis has been based on the interpretation of the account of Cristoforo Buondelmonti, who described the Virgin with raised arms, paratis brachis. ${ }^{93}$ This reading is in accordance with a drawing made for the Apostolic Delegate and Inquisitor to Malta, Fabio Chigi, found in the portfolio of aquarelles that was produced for his office during his stay at Malta in the years 1634-1639, with the handwritten inscription La Madonna di Filermo portata da Rodi. Vedi il Bosio (Fig. 93). The work shows the Virgin Hagiosoritissa in a three-quarter pose, wearing a voluminous maphorion, with her hands raised in prayer toward the miniature figure of a Blessing Christ in the upper-right corner of the composition. The icon is masked by a riza or silver plaque embossed with foliated scrolls inside a gilt frame with the symbols of the four Evangelists in the corners. The Virgin bears a gilt crown decorated with precious stones, and her nimbus is gilt as well; only her face has been sketched uncovered. ${ }^{94}$

91 Idem, 125-126. One of the observations that led her to this conclusion concerning the proposed typology is that the right part of the Virgin's face has been overpainted and initially must have extended further, thus acquiring a more frontal position.

92 Luttrell and O'Malley 2019, 69; Luttrell 2020, 123-124.

93 "Ibique hodie Domina nostra in ecclesia quondam, paratis brachis, visitants adiuvat;" Gerola 1914c, 464; Luttrell 2020, 121. It should be noted that at least 59 manuscripts of Buondelmonti's work exist, with varying text, and that the aforementioned description does not necessarily refer to an icon; one cannot exclude the possibility of a fresco decoration or that the text hints symbolically at prayer or entreaty. Buhagiar has also hypothesized that the Virgin could be part of a Deesis; Buhagiar 2009a, 20. This idea is shared by Ganter, who sees a possible Cypriot provenance and proposes a parallel with the 12thcentury depiction of the Virgin in a Deesis scene from the Monastery of St. Neophytos in Cyprus; Ganter 1968, 107-111.

Ferraris di Celle 1988, 69-72; Buhagiar 2009a, 21-22. 


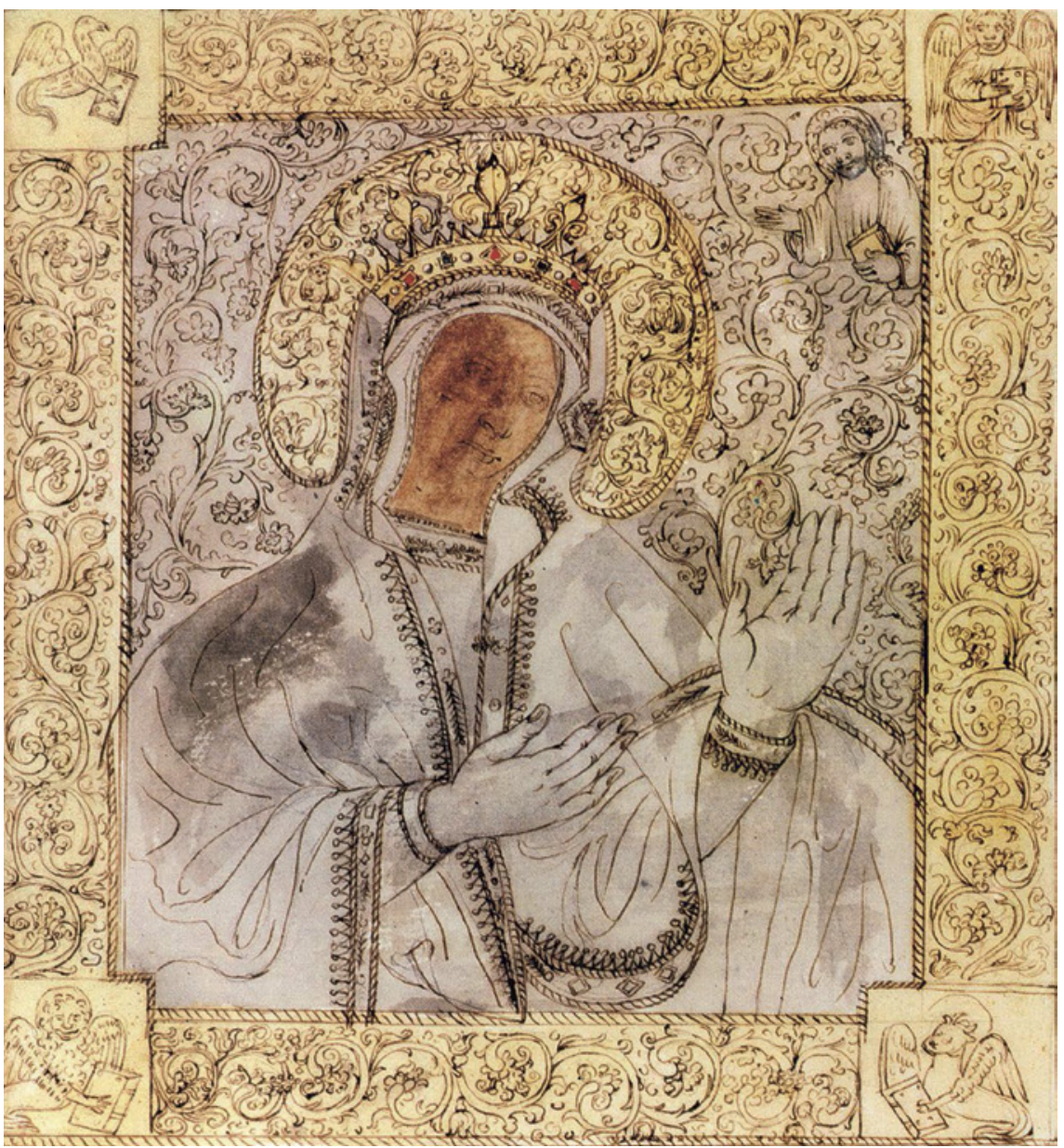

FIGURE 93 La Madonna di Filermo portata da Rodi, 1634-1639, Fabio Chigi's aquarelle portfolio

It is only natural that the decoration of the icon changed over time according to current trends or needs. Its covering is attested by Alessandro di Filippo Rinuccini (1474), who describes "la sua imagine, che in essa si truova dipinta in una tavola et poi addorna di drappo d'oro."95 The golden drapes described by him possibly refer to an icon veil, the precious cloth that was traditionally associated with miraculous icons, as known from the encheirion, or peplos, used 
with the miraculous icons in Constantinople. ${ }^{96}$ In the illustrated inventory in the Metropolitan Cathedral Museum, Mdina, there are two depictions of later coverings — vestiti-for the Madonna of Phileremos, both made of crimson velvet set with pearls, precious stones, and gold. The first one has been dated ca. 1600 and the second to the 17th century, although it bears the arms of Philippe Villiers de L'Isle Adam (1521-1534); perhaps it was reworked (Fig. 94). ${ }^{97}$ These coverings attest to the presentation of the icon at Malta, but do not hint at all to the type of icon underneath. The "dress" carrying the arms of L'Isle Adam was quite possibly commissioned in order to conceal the damage that the icon must have undergone when a fire broke out in 1523 at San Lorenzo in Birgu, where it was held at the time, and its form probably reflects this efforteven though the work was thought to have miraculously escaped damage. ${ }^{98}$

Before the rediscovery of the icon, some light had been shed by copies and old photographs. The first known copy was executed by the painter Semion Basin in Russia in 185 o, but its fate is not known. ${ }^{99}$ In $185^{2}$ a second Russian copy was executed by Vladimir Bovin; ${ }^{100}$ this is currently in the Basilica of Santa Maria degli Angeli at Assisi (Fig. 95). When the Italian government rebuilt the church at Phileremos, it asked for the icon to be returned, but, due to its unknown whereabouts at the time, this Russian copy was sent instead and kept until the Italians left the Dodecanese in 1947. However, during this icon's stay on the island, a Turkish restoration intervened exceedingly with its appearance, as is evident from pictures taken before (Fig. 96). Around 1930, the Italian painter Carlo Cane executed another copy, on the request of the Italian government, which is currently in the church of the Phileremos at Rhodes (Fig. 97).101

In 1866 the icon was photographed for the English members of the Order, and the photographs were given to Sir George Bowyer, ${ }^{102}$ and another photograph, of 1894, was published by Sommi Picenardi (Fig. 98). ${ }^{103}$ It seems, though, that this picture was also taken from the copy and not from the original, when

96 Concerning the tradition of the icon veils and their imperial patronage, see Nunn 1986, 73-102.

97 Oman 1970, 246-247; Buhagiar et al. 1989, 78. Two more vestiti have been described in the manuscript, dated 1687; see Buhagiar 2009a, 21.

98 Ferris 1866, 274; Buhagiar 2017, 68-69.

99 Piatnitsky 2000, 477 .

100 Ibid.

101 On the Russian copy, see Buhagiar 1989c, 20-23; Ferraris di Celle 1988, 41-43; Ferraris di Celle 2009, 56-6o.

102 Piatnitsky 2000, 477.

103 Sommi Picenardi 190o, 216-217. 


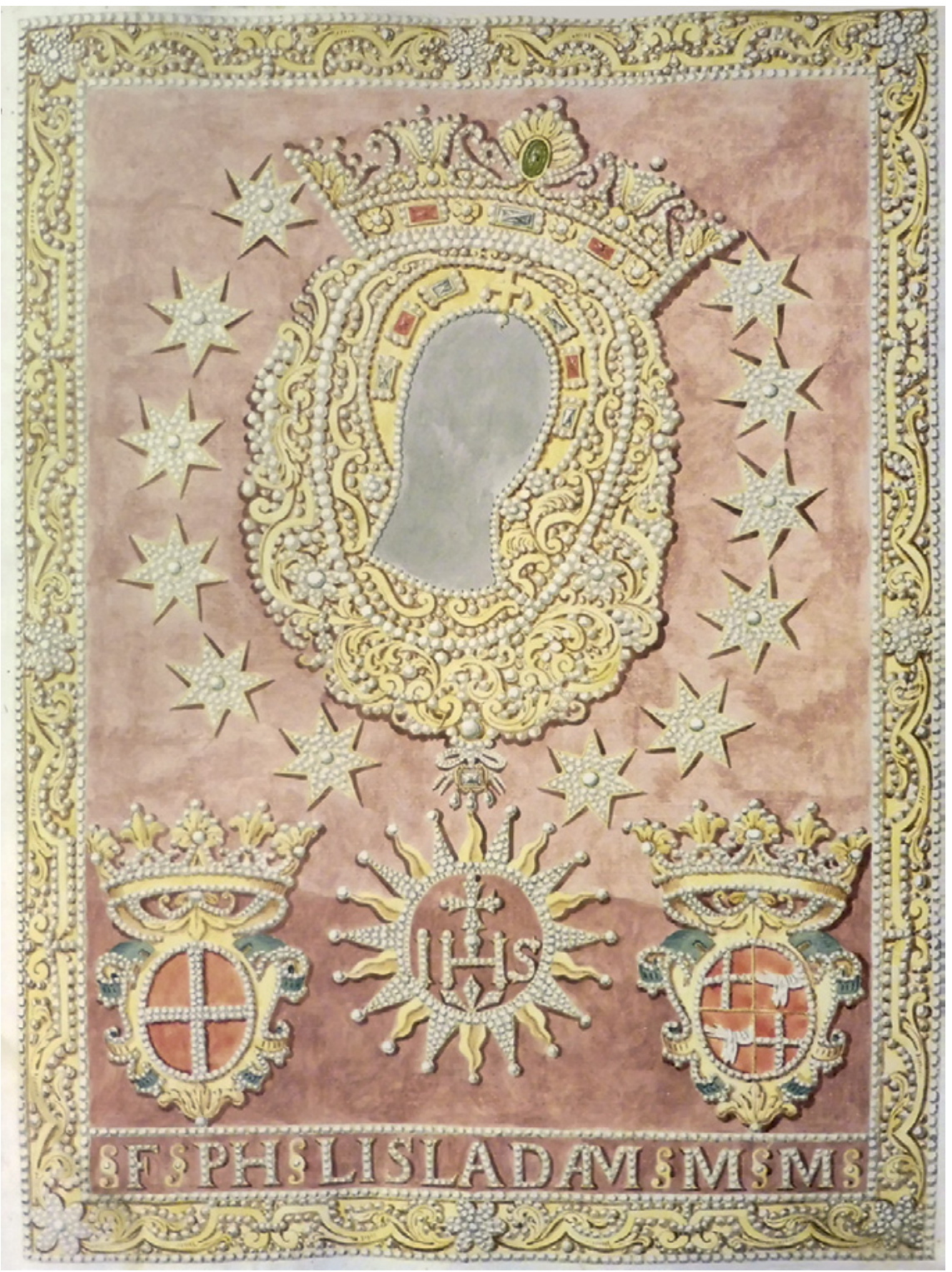

FIGURE 94 A "dress" of the Madonna of Phileremos, 1756, watercolour drawing 


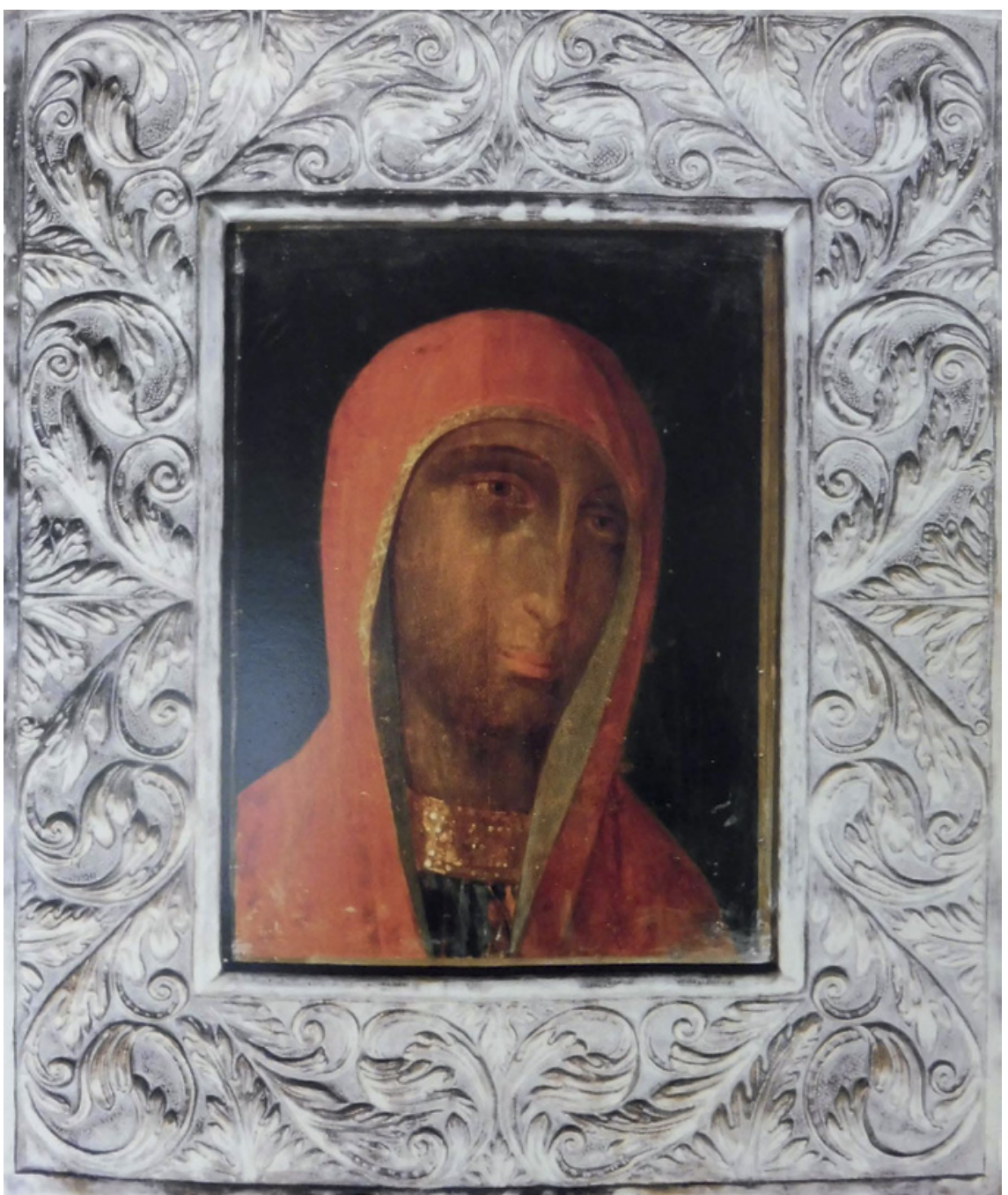

FIGURE 95 Vladimir Bovin, copy of the icon of the Madonna of Phileremos, 1852, Basilica of Santa Maria degli Angeli, Assisi 


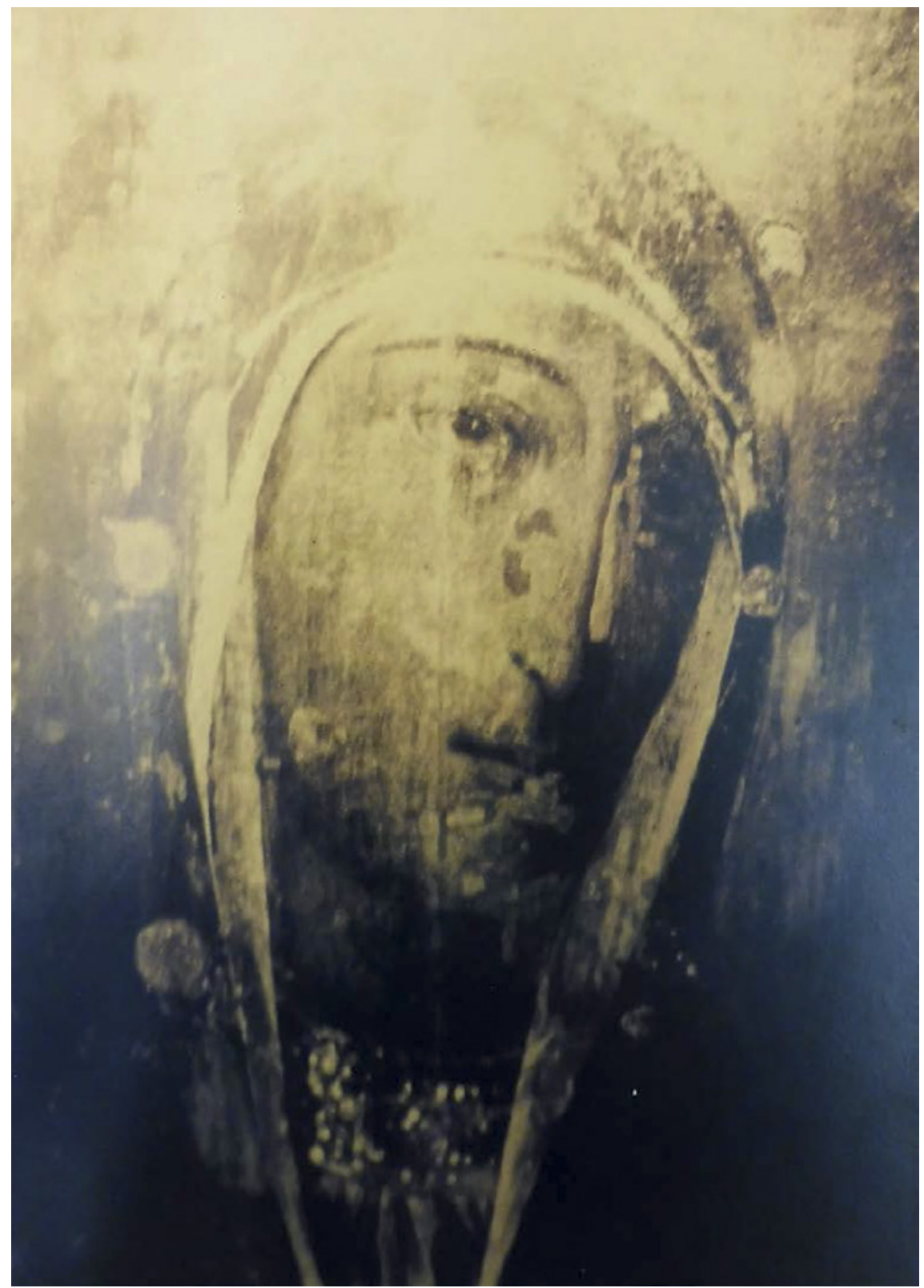

FIGURE 96 Vladimir Bovin, copy of the icon of the Madonna of Phileremos, photograph before the restoration at Rhodes 


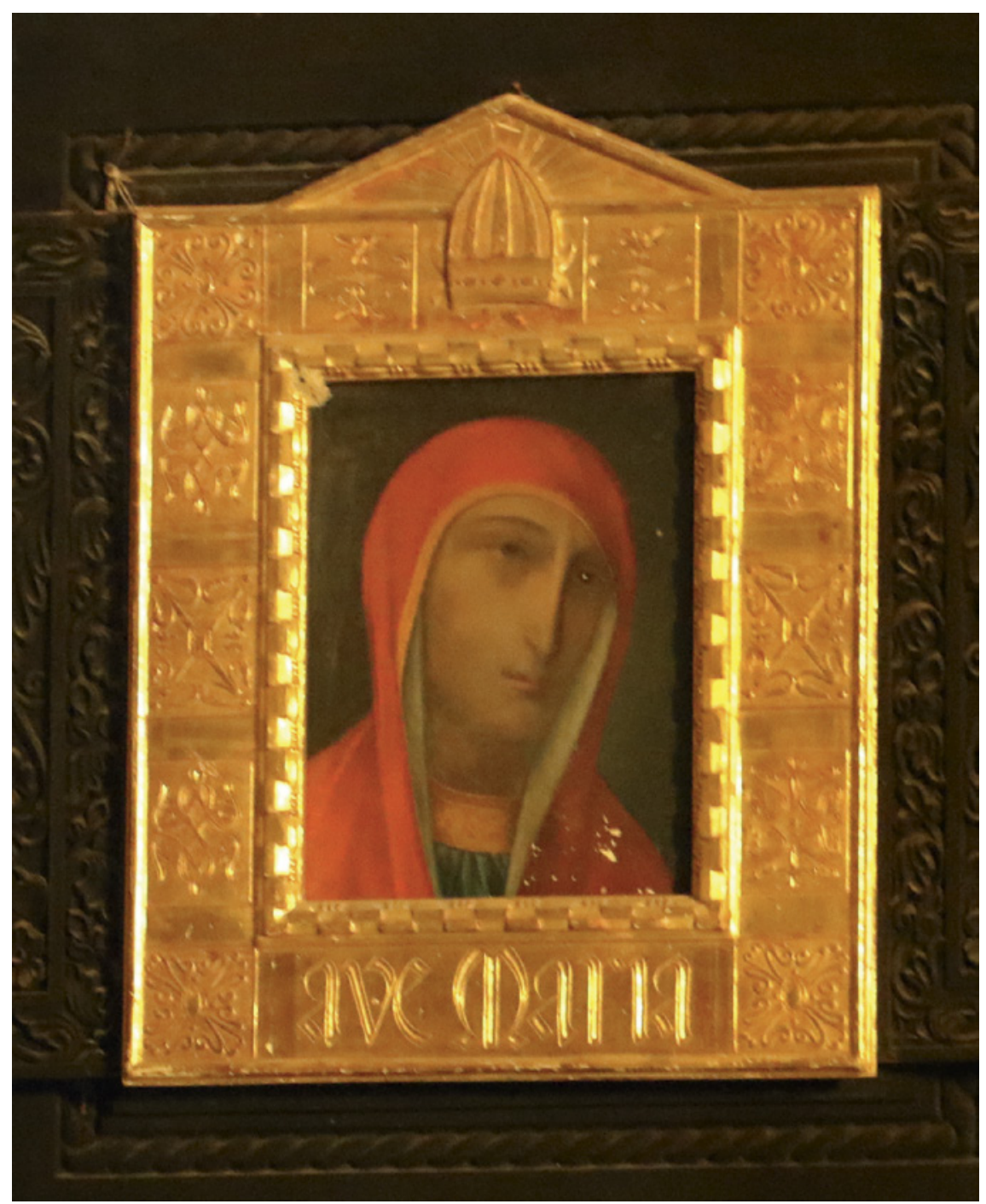

FIGURE 97 Carlo Cane, copy of the icon of the Madonna of Phileremos, ca. 1930, church of Our Lady of Phileremos 


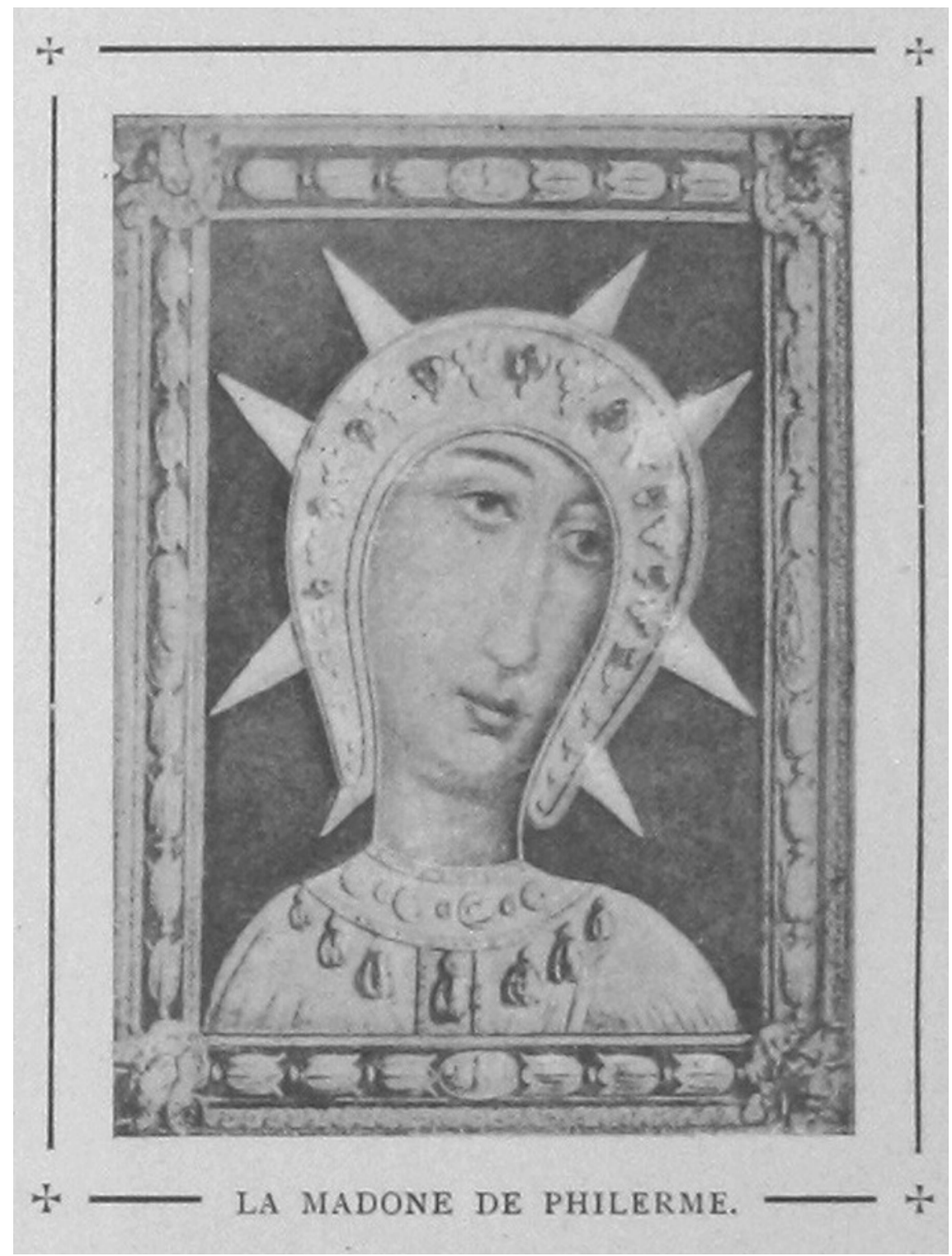

FIGURE 98 The icon of the Madonna of Phileremos, 1894, photograph 


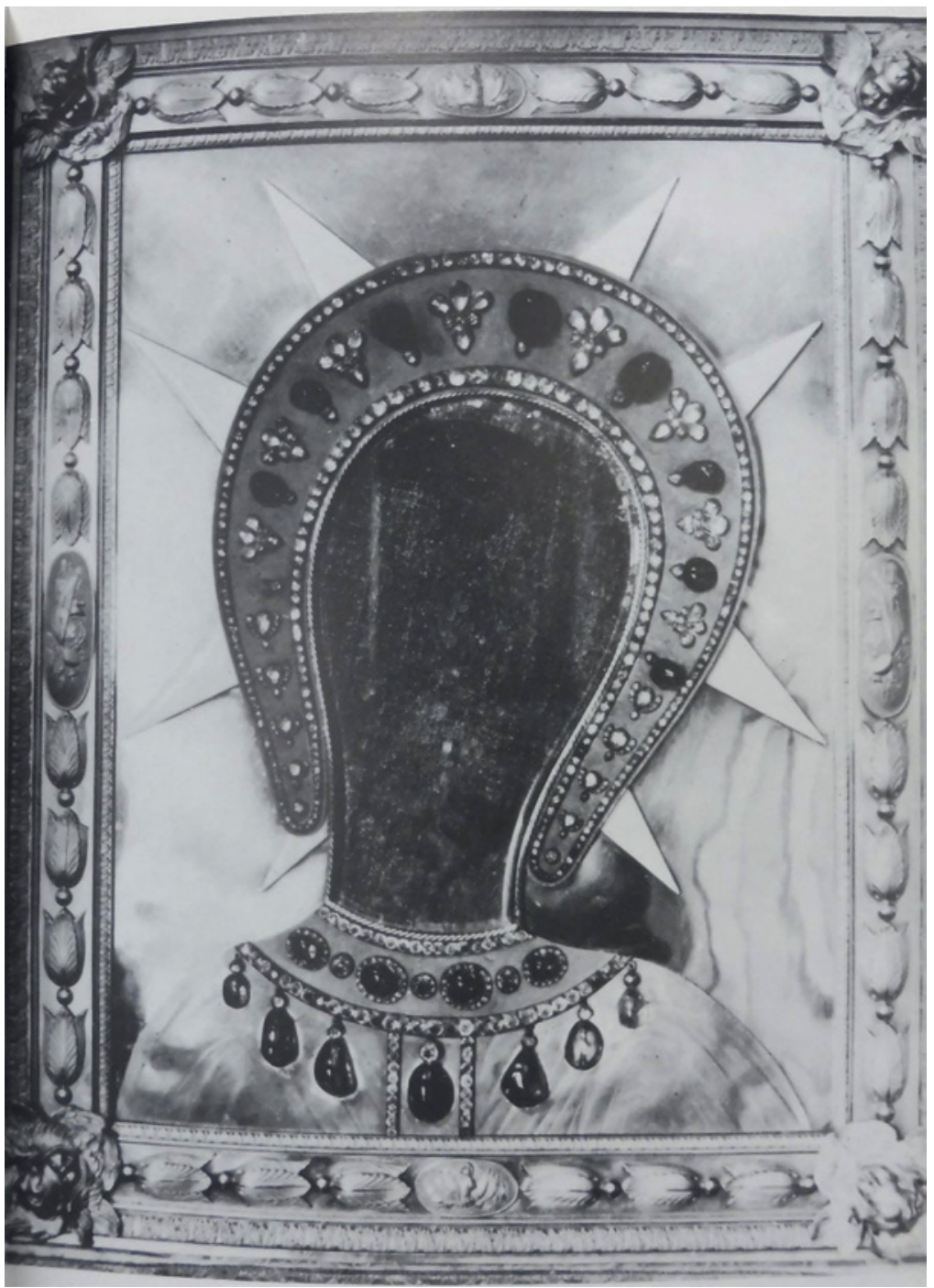

FIGURE 99 The icon of the Madonna of Phileremos, 1932, photograph 
compared with the only certain original photograph taken in Yugoslavia in 1932 (Fig. 99).104 Modern comparison with the icon at Cetinje has confirmed these speculations.

In its present home, the "Blue Chapel" in the National Museum of Montenegro, Cetinje, the icon was examined in 2012 by a conservation team from Belgrade, under Jovan Pantić, together with Veljko Ilić, who recorded the process. The panel and all its elements were photographed in diffuse light, infrared with filters and UV light, and X-rays were taken. The conservators recommended that no further treatment be done, due to the age and fragility of the icon. ${ }^{105}$

104 Buhagiar 1989c, 20-23; Ferraris di Celle 2009, 6o-61.

105 Information kindly provided by Mirjana Dabović Pejović from the National Museum of Montenegro. Unfortunately, the results and reports can be consulted only on site, and a visit was not possible. Gagović was a member of the team from Belgrade and has written a personal estimation of the examination; he states that the icon must have been overpainted during its stay at Russia and that the radiography and the uv shots can lead to a more reliable stylistic and chronological analysis; Gagović 2012, 32. 